Article

\title{
Arf GTPases Are Required for the Establishment of the Pre-Assembly Compartment in the Early Phase of Cytomegalovirus Infection
}

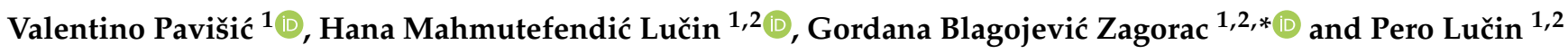 \\ 1 Department of Physiology and Immunology, Faculty of Medicine, University of Rijeka, 51000 Rijeka, Croatia; \\ valentino.pavisic@uniri.hr (V.P.); hana.mahmutefendic@uniri.hr (H.M.L.); plucin@unin.hr (P.L.) \\ 2 Nursing Department, University North, University Center Varaždin, Jurja Križanića 31b, \\ 42000 Varaždin, Croatia \\ * Correspondence: gordana.blagojevic@uniri.hr
}

check for updates

Citation: Pavišić, V.;

Mahmutefendić Lučin, H.;

Blagojević Zagorac, G.; Lučin, P. Arf

GTPases Are Required for the

Establishment of the Pre-Assembly Compartment in the Early Phase of Cytomegalovirus Infection. Life 2021, 11, 867. https://doi.org/10.3390/ life11080867

Academic Editor: Stanislas Tomavo

Received: 27 July 2021

Accepted: 18 August 2021

Published: 23 August 2021

Publisher's Note: MDPI stays neutral with regard to jurisdictional claims in published maps and institutional affiliations.

Copyright: (c) 2021 by the authors. Licensee MDPI, Basel, Switzerland. This article is an open access article distributed under the terms and conditions of the Creative Commons Attribution (CC BY) license (https:/ / creativecommons.org/licenses/by/ $4.0 /)$.

\begin{abstract}
Shortly after entering the cells, cytomegaloviruses (CMVs) initiate massive reorganization of cellular endocytic and secretory pathways, which results in the forming of the cytoplasmic virion assembly compartment $(\mathrm{AC})$. We have previously shown that the formation of $\mathrm{AC}$ in murine CMV- (MCMV) infected cells begins in the early phase of infection (at 4-6 hpi) with the pre-AC establishment. Pre-AC comprises membranes derived from the endosomal recycling compartment, early endosomes, and the trans-Golgi network, which is surrounded by fragmented Golgi cisterns. To explore the importance of Arf GTPases in the biogenesis of the pre-AC, we infected Balb 3T3 cells with MCMV and analyzed the expression and intracellular localization of Arf proteins in the early phases (up to $16 \mathrm{hpi}$ ) of infection and the development of pre-AC in cells with a knockdown of Arf protein expression by small interfering RNAs (siRNAs). Herein, we show that even in the early phase, MCMVs cause massive reorganization of the Arf system of the host cells and induce the over-recruitment of Arf proteins onto the membranes of pre-AC. Knockdown of Arf1, Arf3, Arf4, or Arf6 impaired the establishment of pre-AC. However, the knockdown of Arf1 and Arf6 also abolished the establishment of infection. Our study demonstrates that Arf GTPases are required for different steps of early cytomegalovirus infection, including the establishment of the pre-AC.
\end{abstract}

Keywords: Arf GTPases; cytomegaloviruses; pre-assembly compartment; Rab10; m06

\section{Introduction}

Cytomegaloviruses (CMVs) are widespread double-stranded DNA betaherpesviruses that mostly cause asymptomatic infection followed by a long-lasting latent state. In immunocompromised individuals, acute infection and reactivation from this latency can lead to life-threatening conditions [1-3]. CMVs virions are composed of dsDNA encased in capsid surrounded by tegument and envelope glycoproteins. Murine CMV (MCMV) shares many similarities with other betaherpesviruses and is used as a model for studying betaherpesvirus biology in vitro and in vivo. MCMV, upon entry, activates a gene-expression program, which is executed through three phases: immediate-early (IE), which lasts up to $2 \mathrm{~h}$ post-infection (hpi), early (E; from 2 to $16 \mathrm{hpi}$ ), and late (L; after 16 hpi) [4].

In the early stages of infection, CMV induces the reorganization of intracellular membranes and hijacks many cellular proteins as well as endocytic and secretory pathways of the host cells to form the virion assembly compartment (AC). The AC is a large and complex structure that is developed from the reorganized membranous organelles of the cell [5]. The onset of AC formation in murine MCMV-infected cells can be identified at 4-6 hpi as an extensive reorganization of the Golgi and the endosomal system [6,7]. A similar set of events was executed during HCMV infection with significantly delayed kinetics [8-11]. 
Studies on HCMV have demonstrated the alteration of expression of a large number of cellular genes and proteins that organize membranous organelle systems, and studies on both HCMV and MCMV indicate the extensive reorganization of early endosomes (EEs), the endosomal recycling compartment (ERC), and the trans-Golgi (TGN) related organelles [7-10,12]. The first reorganized structure observed at 6 hpi evolves throughout the early phase, which in MCMV infected cells lasts up to 15-16 h after infection. The end of the early phase is denoted by the initiation of viral DNA replication followed by the expression of a large set of MCMV-encoded gene products, known as late genes. Many of these gene products embed into the reorganized membranous organelles and further drive the maturation of the AC. In general, we consider the reorganized structures that involve the Golgi and EE-ER-TGN-derived organelles to be present during the early phase of infection as pre-AC, whereas these structures that are introduced upon the integration of the late-gene products as AC [6].

One of the hallmarks of reorganized membranous organelles in the pre-AC is extensive tubulation. The tubulation in the membranous system of uninfected cells is driven by small GTPases from the Ras family, especially members of the Arf subfamily. Arf proteins are small $(\sim 20 \mathrm{kDa})$ monomeric GTPases that control intracellular trafficking within the secretory [13-15] and endocytic [16-18] pathways. Arf proteins, similar to other small GTPases, function as molecular switches and cycle between their inactive (GDP-bound) and active (GTP-bound) form $[13,14,16]$. The activation of Arfs is spatially and temporally regulated by guanine nucleotide exchange factors (GEFs), proteins that facilitate the exchange of GDP to GTP, and GTPase activating proteins (GAPs), which facilitate the exchange of GTP to GDP. Activated Arf proteins bind to membranes and recruit different effector proteins, thereby regulating downstream processes $[19,20]$.

Based on their sequence homology, Arfs are divided into class I (Arf1, Arf2, and Arf3), class II (Arf4 and Arf5), and class III (Arf6) [13,14]. Murine and human cells do not express Arf2 [21] Class I and II predominantly act in the secretory pathway (the endoplasmic reticulum and the Golgi), where they regulate vesicle budding by recruiting coat complexes [13-15,22,23], but they also act in the endosomal system and trans-Golgi network (TGN) [24-28]. Arf1 and Arf3 also regulate transport between GA and TGN [29,30]. In the endosomal system, Arf1 regulates the endocytosis of GPI-anchored proteins [31], Arf1 and Arf4 regulate the retrograde transport of recycling endosomes to the TGN [25], while Arf1 and Arf3 control recycling from the early stage and recycling endosomes to the PM [24]. Arf6 is the only member of the Arf family that does not play a part in the secretory pathway $[13,14,17,32,33]$ but regulates various processes within the endosomal system, including endocytosis [26,34-37], actin cytoskeleton dynamics [38-40], endosomal recycling [41-44], and organization of the ERC [17,45]. Many downstream effector functions of Arf proteins are associated with the tubulation of membranous organelles and the development of transport carriers.

The role of Arf proteins has been studied in the pathogenesis of several bacterial and viral infections $[39,46-51]$, while their role in the pathogenesis of CMV infection has been understudied. A study of human CMV infection suggested impaired Arf6 function associated with the reprogramming of endosomal trafficking [52]. Our recent studies on murine CMV (MCMV) demonstrated the over-recruitment of all Arf isoforms within the $\mathrm{AC}$ in the late phase of infection, at $48 \mathrm{hpi}$ [6]. However, the dynamics of Arf expression during the MCMV infection cycle, intracellular localization in the early phase of infection, and their role in pre-AC formation have not been examined in detail.

Therefore, this study aimed to analyze the contribution of class I, II, and III Arf proteins in the biogenesis of the pre- $\mathrm{AC}$ membranous organelle reorganization events during the early phase of infection. We analyzed the expression level of all Arf isoforms and their localization during the early phase of MCMV infection. A much shorter duration of the early phase during MCMV infection enabled systematic analysis of early phase events under the conditions of the long-term knockdown of all Arfs by small interfering RNAs (siRNA silencing). Our study demonstrates the overexpression of class I and II Arfs, the 
over-recruitment of all Arfs at membranes of the pre-AC, and the requirement of Arf1, Arf3, Arf4, and Arf6 for the development of the pre-AC. However, our study also revealed that the contribution of Arf1 and Arf6 is most likely associated with the earliest stages of infection, either during virion entry or during the establishment of infection. Given that many processes of the AC biogenesis are conserved among beta-herpesviruses, our data may contribute to understanding the biogenesis of the HCMV assembly compartment and to identifying the host cell processes that may be targeted for the development of antivirals.

\section{Materials and Methods}

\subsection{Cell Lines, Viruses, and Infection Conditions}

All experiments were performed on Balb $3 \mathrm{~T} 3$ fibroblasts that were obtained from American Type Culture Collection (ATCC, clone A31, ATCC CCL-163). Cells were cultured in Dulbecco's modified Eagle's medium supplemented with $10 \%$ fetal bovine serum (FBS), $2 \mathrm{mM}$ L-glutamine, $100 \mathrm{mg} / \mathrm{mL}$ of streptomycin, and $100 \mathrm{U} / \mathrm{mL}$ penicillin (Gibco/Invitrogen, Grand Island, NY, USA) at $37^{\circ} \mathrm{C}$ in $5 \% \mathrm{CO}_{2}$.

The recombinant virus $\triangle \mathrm{m} 138-\mathrm{MCMV}$ (MC95.15) with the deletion of the for1 (m138) gene [53] was regularly used for infection. Cells were infected at a multiplicity of infection (MOI) of 5-10 with infectivity enhancment by centrifugation [54]. Detection of the immediate-early 1 (IE1) protein was used to determine the effectiveness of the infection [7]. In some experiments, the cells were infected at the same MOI with C3X-GFP MCMV (a kind gift from M. Messerle), in which a GFP expression cassette was inserted in front of the ie2 gene [55] since it was previously shown that foreign genes could be inserted at this location without affecting the growth of the recombinant MCMV.

\subsection{Antibodies}

Rabbit polyclonal anti-Arf1, rabbit polyclonal anti-Arf3, and rabbit polyclonal antiArf5 antibodies were purchased from Abcam (Cambridge, UK); monoclonal mouse antiArf3 and anti-GM-130 antibodies were from BD Transduction Laboratories (San Jose, CA, USA); rabbit polyclonal anti-Arf4 and mouse monoclonal anti-Arf5 antibodies were purchased from LSBio (Seattle, WA, USA); rabbit monoclonal anti-Arf6 and rabbit monoclonal anti-Rab10 antibodies were from Cell Signalling (Danvers, MA, USA); and mouse anti- $\beta$ actin was from Millipore (Billerica, MA, USA). The MAbs to murine transferrin receptor (TfR) (clone R17 217.1.3) was used as a hybridoma culture supernatant purified by affinity chromatography. Mouse monoclonal antibodies to MCMV proteins IE1 (clone IE1.01 and clone CRO101) and m06 (clone CROMA229) were produced and validated by the University of Rijeka Center for Proteomics. Alexa Fluor (AF) ${ }^{488}$ - and $\mathrm{AF}^{555}$-conjugated secondary antibody reagents to mouse $\operatorname{IgG}_{2 a}$, mouse $\operatorname{IgG}_{1}$, rat $\mathrm{IgG}$, and rabbit IgG were from Molecular Probes (Leiden, Netherlands), and AF ${ }^{60}$-conjugated IgG1 and $\operatorname{IgG}_{2 \mathrm{a}}$ as well as peroxidase-conjugated secondary reagents to mouse and rabbit IgG, were from Jacksons Laboratory (Bar Harbor, ME, USA).

\section{3. siRNA Silencing}

FlexiTube small interfering RNA (siRNA) to Arf1 (GS11840), Arf3 (GS11842), Arf4 (GS11843), Arf6 (GS11845) as well as a non-targeting negative control siRNA (1022076) were purchased from Qiagen (Hilden, Germany), and the siRNA of Arf5 (4390771) was purchased from Ambion (Berlin, Germany). Cells were transfected with the siRNAs using RNAiMAX Lipofectamine reagent (Invitrogen, Carlsbad, CA, USA) according to manufacturer guidelines, with the final siRNAconcentration being $20 \mathrm{nM}$ unless otherwise indicated. The cells proceeded to experimental procedure $72 \mathrm{~h}$ after transfection. Transfection specificity and efficiency were monitored by Western blot and immunofluorescence microscopy.

\subsection{Immunofluorescence and Confocal Analysis}

Cells grown on coverslips were fixed for $20 \mathrm{~min}$ with $4 \%$ PFA at RT and were permeabilized for $20 \mathrm{~min}$ with $0.5 \%$ Tween 20 at $37^{\circ} \mathrm{C}$. After permeabilization, the cells were 
incubated with primary Abs for 60-90 min at RT, the unbound Abs were washed with PBS, and the cells were incubated for $60 \mathrm{~min}$ with an appropriate fluorochrome-conjugated secondary reagent. After three washes in PBS, the cells were embedded in Mowiol (Fluka Chemicals, Selzee, Germany)—DABCO (Sigma Chemical Co, Steinheim, Germany) in PBS containing $50 \%$ glycerol and were analyzed using confocal microscopy.

Imaging was performed on an Olympus Fluoview FV300 confocal microscope (Olympus Optical Co., Tokyo, Japan) equipped with Ar488, He/Ne 543, and He/Ne 633 lasers. The images were acquired using Fluoview software, version 4.3 FV 300 (Olympus Optical Co., Tokyo, Japan), PLAPO60xO objective, appropriate filters, and PMT detectors. The $\mathrm{z}$-series of $0.5 \mu \mathrm{m}$ optical sections were acquired sequentially with medium scan speed $(1.65 \mathrm{~s} / \mathrm{scan})$. Images $(515 \times 512$ pixels) were captured at different zoom values (zoom factor: $0.75-6.0$ ) with pixel sizes from $481.47 \mathrm{~nm} \times 481.47 \mathrm{~nm}$ to $60.18 \mathrm{~nm} \times 60.18 \mathrm{~nm}$. Confocal images were exported in a TIFF format and were analyzed using ImageJ 1.53c software. Focus plane images were used for image presentation and colocalization presentation by plotting profiles along the line. Borders of cells and nuclei were determined through overlapping immunofluorescence and transmission light microscope images.

Colocalization was quantitatively evaluated on images with a pixel size of $60.18 \mathrm{~nm}$ $\times 60.18 \mathrm{~nm}$ and $120.37 \mathrm{~nm} \times 120.37 \mathrm{~nm}$ using the JACoP plugin [56] to calculate Manders' overlap coefficients. The best-fit lower threshold to eliminate most of the signal background (Costes automatic thresholding method) was determined using the threshold tool and was confirmed by visual inspection. Measures were made on the entire z-series of 9-13 cells from 2-3 independent experiments.

The percentages of cells with juxtanuclear Rab10 accumulation, nuclear IE1, or cytoplasmatic m06 expressions were determined directly during microscopy (Olympus Fluoview FV300 confocal microscope, PLAPO60xO objective) and on images captured with the zoom factors of 0.75 and 1.5. At least 10 fields of view ( 8-30 cells/field) were analyzed from each of the two to three independent experiments.

\subsection{Quantification of Infection by Flow Cytometry}

Uninfected or C3X-GFP MCMV-infected cells were collected through short trypsin treatment, washed in PBS containing $10 \mathrm{mM}$ EDTA, HEPES $\mathrm{pH}=7.2,0.1 \% \mathrm{NaN} 3$, and $2 \%$ FCS (PBS-A), and the GFP fluorescent signal was analyzed by means of flow cytometry using a FACSCalibur flow cytometer (Becton Dickinson \& Co, San Jose, CA, USA). Dead cells were excluded using propidium iodide $(1 \mu \mathrm{g} / \mathrm{mL})$, and 10,000 viable cells were acquired. The fluorescence signal was determined as the mean fluorescence intensity (MFI) after subtracting the background fluorescence $(\Delta \mathrm{MFI})$ determined in the uninfected cells. The percentage of infected cells was calculated after thresholding on cells infected with C3X-GFP MCMV at 0 hpi.

\subsection{Western Blot Analysis}

RIPA lysis buffer supplemented with protease and phosphatase inhibitors was used for the preparation of cellular extracts for WB analysis. Samples were separated by SDS-PAGE and were blotted onto a polyvinylidene difluoride (PVDF-P) WB membrane (Millipore, Billerica, MA, USA) at 60 to $70 \mathrm{~V}$ for $1 \mathrm{~h}$. Membranes were incubated with $1 \%$ blocking reagent (Roche Diagnostics GmbH, Mannheim, Germany) for $1 \mathrm{~h}$. After three cycles of washing with $0.5 \%$ TBS-T buffer ( $\mathrm{pH} 7$ ), the membranes were incubated with a peroxidaseconjugated secondary reagent diluted in TBS buffer containing $0.5 \%$ blocking reagent for $45 \mathrm{~min}$. After being washed three times with TBS-T buffer, the membranes were incubated for 1 min with ECL Prime substrate (GE Healthcare, Chicago, IL, USA), and signals were detected by Transilluminator Alliance 4.7 (Uvitec Ltd., Cambridge, UK).

Western blot signals were quantified by using ImageJ software according to published protocols [57], and signals were normalized to associated actin control. Briefly, the normalization factor for every lane was calculated as a ratio between the observed actin signal for every lane and the highest observed signal of the actin for the blot. Normalized 
experimental signals were calculated by dividing the observed experimental signal by the lane normalization factor.

\subsection{Statistics}

The data are presented as means \pm standard deviation. The significance of difference was tested using a two-tailed Student's $t$-test, and differences were considered to be significant if $p$ was $<0.005$. The asterisk above the error bars indicates statistical significance using the group transfected with non-targeting, scramble (SCR.) siRNA as the control group.

\section{Results}

3.1. Increased Expression of Class I Arf Proteins and Their Accumulation in the Pericentriolar Region of MCMV-Infected Cells at the Time of the Pre-AC Establishment

Our previous study demonstrated the accumulation of Arf (Arf1-6) proteins at the AC in the late phase of MCMV infection (at $48 \mathrm{hpi}$ [ [6]. Thus, we first analyzed the expression level and intracellular recruitment of all Arf proteins in the early phase of infection at the pre-AC stage. Considering that the reorganization of the membranous system and the development of the pre-AC in MCMV-infected cells is initiated already 5-6 h after infection $[7,12,58]$, we analyzed their expression level by Western blot throughout the entire early phase of infection, up to $16 \mathrm{hpi}$, which is when viral DNA synthesis begins [59]. The intracellular localization was analyzed by double immunofluorescence staining and confocal microscopy at $6 \mathrm{hpi}$, a time when pre-AC rearrangement was observed in approximately half of the infected cells, and at $16 \mathrm{hpi}$, at the end of the early phase when, $\sim 90 \%$ of the infected cells establish full pre-AC [7,12]. To avoid the unspecific capture of antibody reagents by a MCMV protein with a Fc receptor property, we infected cells with a recombinant virus $\triangle \mathrm{m} 138$-MCMV. MCMV-encoded immediate-early 1 (IE1) protein expression, which localizes in the nucleus of infected cells, was used to control infection.

We first analyzed the class I Arf proteins represented by Arf1 and Arf3 in murine cells. As demonstrated in Figure 1, both the Arf1 and Arf3 proteins were upregulated in MCMV-infected cells. The increased amount of Arf1 was already detected $2 \mathrm{~h}$ postinfection (hpi), as demonstrated by the representative Western blot (Figure 1A), and it was maintained throughout the entire early phase, up to the 16th hour of infection. The intracellular amount of Arf1 was approximately doubled, as determined by quantification of the Arf1 signal relative to the actin from the same samples (Figure 1B). A similar pattern was observed for Arf3 in the early phase of infection (Figure 1D,E). These data indicate that class I Arf proteins are rapidly upregulated in MCMV-infected cells, which can be a consequence of either increased synthesis or slowed degradation. The rapidity of upregulation together with the analysis of the host cell transcriptome, which demonstrated no significant alteration in any of the mRNAs of the Arf proteins in the early phase of infection [6], suggest that observed increases of the levels of Arf proteins are more likely due to altered mechanisms controlling endogenous class I Arf protein degradation rather than a consequence of altered synthesis. 


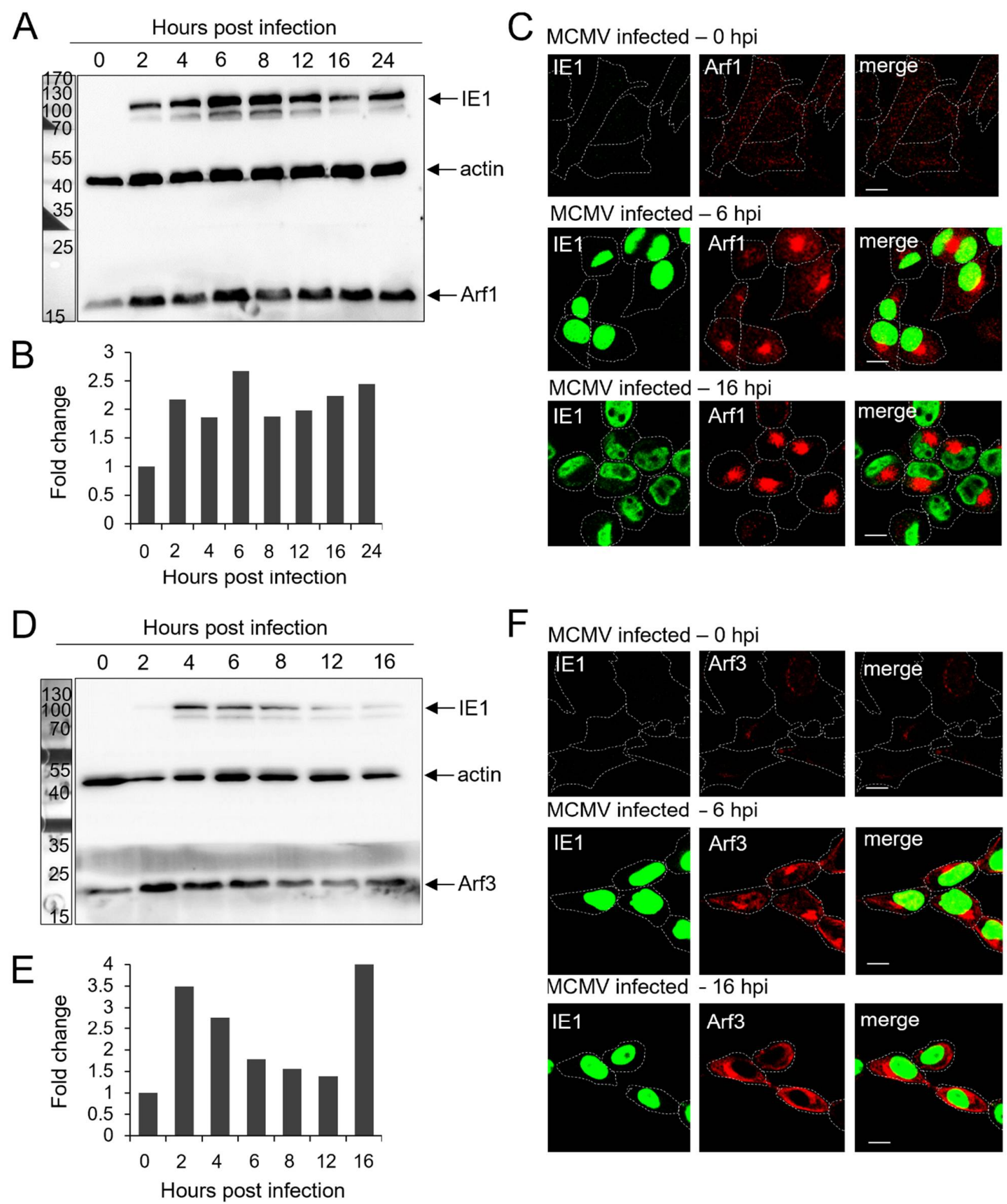

Figure 1. Expression levels of class I Arf proteins and their intracellular localization in the MCMV-infected cells during the early phase of infection. Balb 3T3 cells were infected with $\triangle \mathrm{m} 138-\mathrm{MCMV}$, and the expression level and intracellular recruitment of Arf1 and Arf3 in the early phase of MCMV infection (0-16 hpi) were analyzed by Western blot and immunofluorescence. Representative Western blots of Arf1 (A) and Arf3 (D) expression in the early phase of MCMV infection are presented. Actin was used as a loading control, and IE1 expression was used as an infection control. Protein markers are shown on the left. Quantitative analysis of Arf1 (B) and Arf3 (E) expression levels was performed as described in Materials and Methods. Results are expressed as a fold change relative to Arf expression in 0 hpi MCMV-infected cells. Immunofluorescence images of Arf1 (C) and Arf3 (F) expression relative to the nuclear staining of the immediate-early 1 (IE1) MCMV protein during the early phase of infection. $\triangle$ m138-MCMV-infected Balb $3 T 3$ cells were fixed at 0, 6, and $16 \mathrm{hpi}$, permeabilized, and stained against IE1 and either Arf1 or Arf3. The antibodies were visualized with the appropriate fluorochrome-conjugated non-crossreactive secondary reagents. Cell borders are indicated by dashed lines. Bars, $10 \mu \mathrm{m}$. 
The endogenous expression level and membrane recruitment of Arf1 (Figure 1C) and Arf3 (Figure 1F) was relatively low in Balb 3T3 cells immediately after infection (0 hpi), which was similar to the uninfected cells [6]. Thus, we further examined whether the increased protein level was associated with the increased recruitment at the reorganized membranes of the pre-AC. As demonstrated in Figure 1C,F, both Arf1 and Arf3 were highly recruited at the reorganized membranes in the perinuclear area of the MCMV-infected cells already at $6 \mathrm{hpi}$ and even more at $16 \mathrm{hpi}$. Given that we set up $6 \mathrm{hpi}$ as the earliest time in the development of the pre-AC, which consistently displays the pre-AC structure in $\sim 55 \%$ of cells $[6,7,12]$, these data indicate that the accumulation of class I Arfs is associated with the dysregulation of the membranous system that leads to the establishment of the pre-AC. Interestingly, Arf3 was also highly recruited to membranous structures at the cell periphery, including the subplasmalemmal area (Figure $1 \mathrm{~F}$ ), suggesting the dysregulation of the peripheral membranous system outside of the pre-AC of MCMV-infected cells. Note that recruitment of both Arf1 and Arf3 at 6 hpi (Figure 1C,F) was not associated with full cell rounding and contraction, suggesting that the it is a consequence of a membranous organelle rather than cytoskeleton dysregulation.

\subsection{Increased Expression of Class II Arf Proteins in the Early Phase of Infection and Their Recruitment at Membranes of the Pre-AC}

We next analyzed the expression of class II Arfs during the early phase of MCMV infection. Similar to class I Arfs, both of the class II Arf proteins also rapidly increased the expression level (Figure 2). Arf4 increased by 3-4 fold (Figure 2B), whereas Arf5 almost doubled in amount (Figure 2D) at $4 \mathrm{hpi}$, and both Arfs remained elevated during the entire early phase of infection (Figure 2A,B,D,E).

As demonstrated for the class I Arfs, Arf4, and Arf5 displayed a low level of endogenous expression and membrane recruitment in the MCMV-infected cells immediately after infection (Figure 2C,F), similar to what was observed in the uninfected cells [6]. In contrast to the class I Arfs, Arf4 (Figure 2C) and Arf 5 (Figure 2F) were not highly recruited to the perinuclear membranous organelles of the MCMV-infected cells at 6 hpi, although their expression levels were increased at that time point, espically that of Arf5. At 16 hpi, both Arf4 and Arf5 were highly recruited to membranes in the perinuclear area and were also highly recruited to the peripheral membranous structures of infected cells. These data indicate that the accumulation of class I Arfs coincides with the establishment of the pre-AC structure, whereas class II Arfs are recruited to the pre-AC membranes somewhat later.

\subsection{Recruitment of Arf6 (Class III Arf Protein) at Membranes of the Pre-AC without Increased Expression in the Early Phase of MCMV Infection}

In contrast to the class I and class II Arfs, Arf6 did not show an increased expression level during the early phase of MCMV infection (Figure 3A,B). Although the plasma membrane (PM) is the established localization of Arf6 [35], in uninfected Balb 3T3 cells [6] and MCMV-infected cells immediately after infection (0 hpi), Arf6 was found at membranous structures dispersed through the cell cytoplasm and was not detected on the PM (Figure 3C). At 6 hpi, in most MCMV-infected cells, Arf6 was still at dispersed membranous structures, and was found to be accumulated in the perinuclear area in a small number of cells (Figure 3C). The signal of Arf6 cytoplasmic staining was increased, likely due to the cell contraction and the increasing time of infection coalesced to the juxtanuclear area. At 16 hpi, Arf6 was found accumulated in the juxtanuclear area of MCMV-infected cells. These data indicate that MCMV infection does not change the cellular amount of Arf6 but induces the dysregulation of the Arf6 recruitment cycle, resulting in its accumulation at the membranes of the pre-AC. Since this recruitment is not a prominent feature of $6 \mathrm{~h}$-infected cells, these data suggest that the Arf6 recruitment dysregulation occurs in the sequence after the recruitment of class I Arfs. 

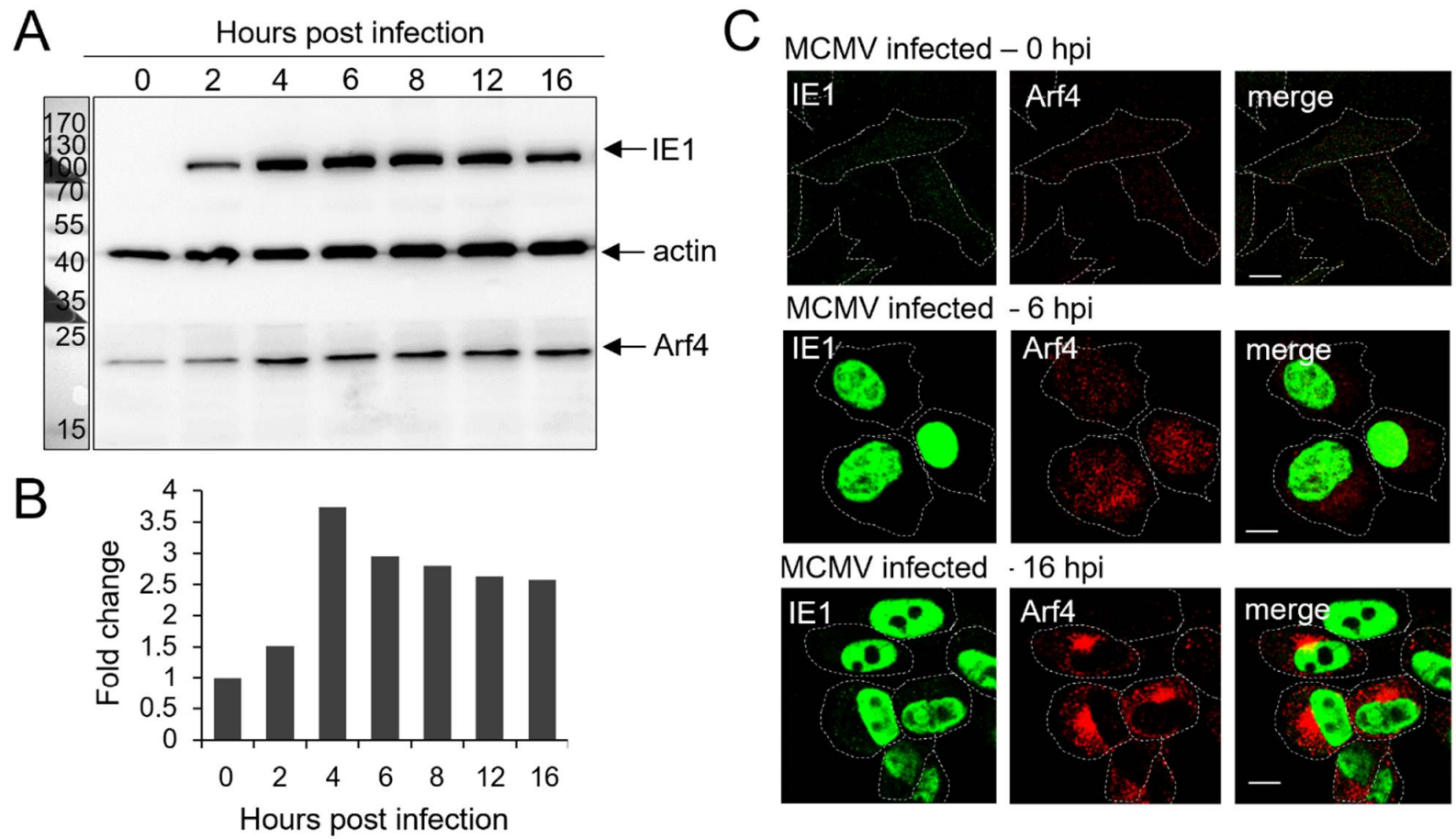

MCMV infected $\cdot 16 \mathrm{hpi}$
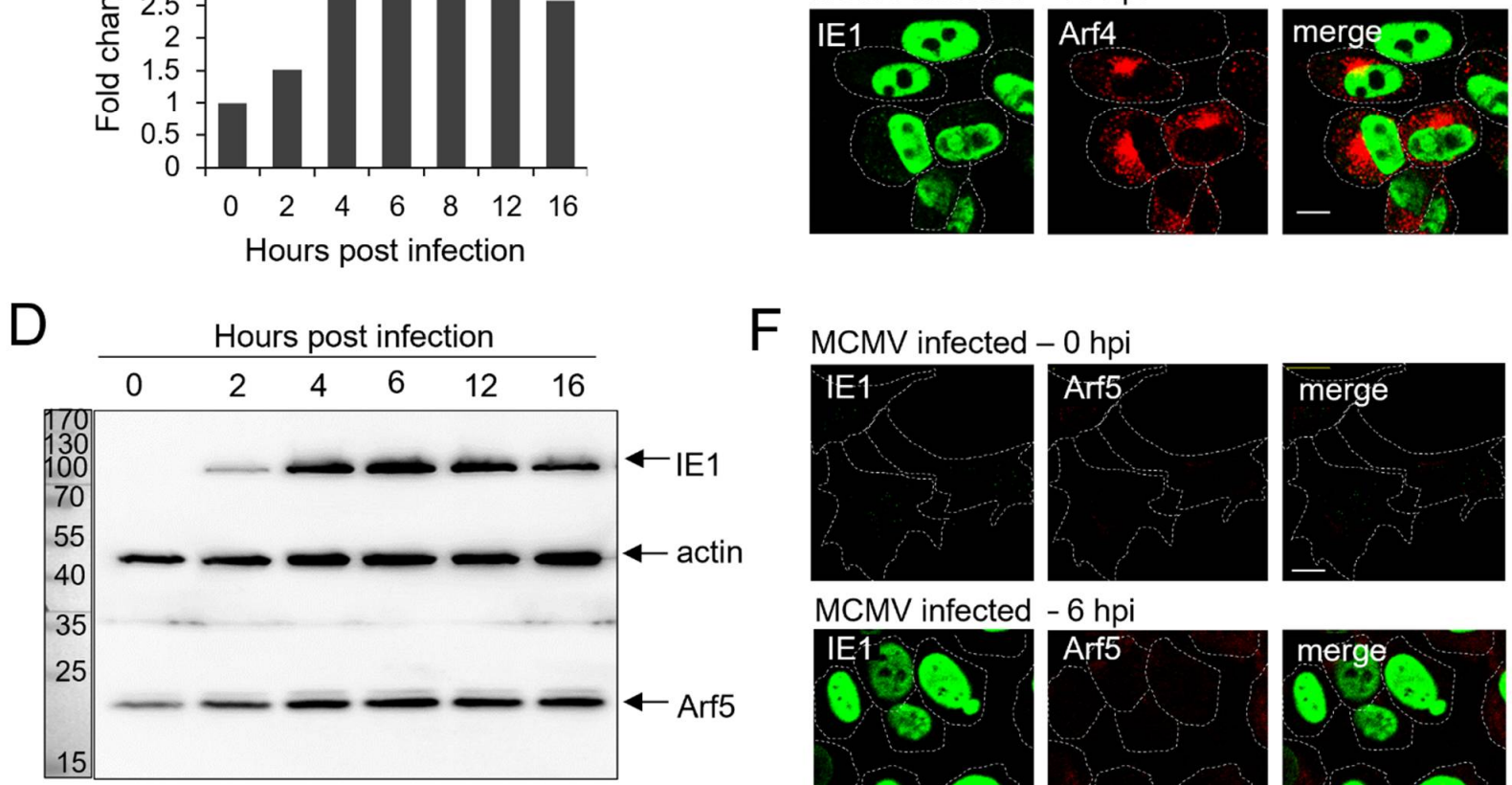

MCMV infected -6 hpi
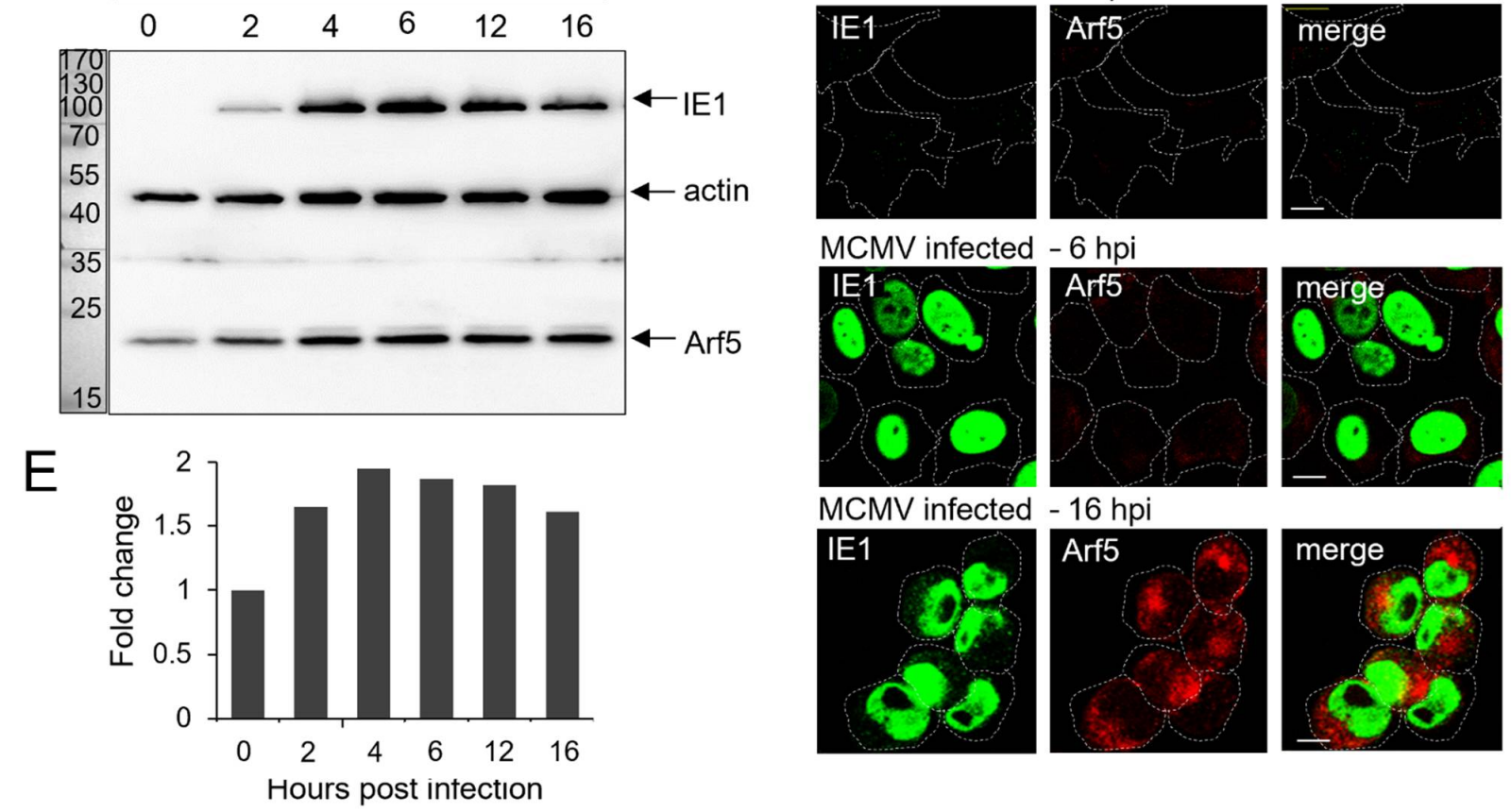

Figure 2. Expression levels of class II Arf proteins and their intracellular localization in the MCMV-infected cells during the early phase of infection. Balb $3 \mathrm{~T} 3$ cells were infected with $\triangle \mathrm{m} 138-\mathrm{MCMV}$, and the expression level and intracellular recruitment of Arf4 and Arf5 in the early phase of MCMV infection (0-16 hpi) were analyzed by Western blot and immunofluorescence. Representative Western blots of Arf4 (A) and Arf5 (D) expression in the early phase of MCMV infection are presented. Actin was used as a loading control, and IE1 expression was used as a control of infection. Protein markers are shown on the left. Quantitative analysis of Arf4 (B) and Arf5 (E) expression levels was performed as described in Materials and Methods. Results are expressed as a fold change relative to Arf expression in 0 hpi MCMV-infected cells. Immunofluorescence images of Arf4 (C) and Arf5 (F) expression relative to the nuclear staining of immediate-early 1 (IE1) MCMV proteins during the early phase of infection. $\triangle \mathrm{m} 138-\mathrm{MCMV}$-infected Balb 3T3 cells were fixed at 0,6, and $16 \mathrm{hpi}$, permeabilized, and stained against IE1 and either Arf4 or Arf5. The antibodies were visualized with the appropriate fluorochrome-conjugated non-crossreactive secondary reagents. Cell borders are indicated by dashed lines. Bars, $10 \mu \mathrm{m}$. 
A

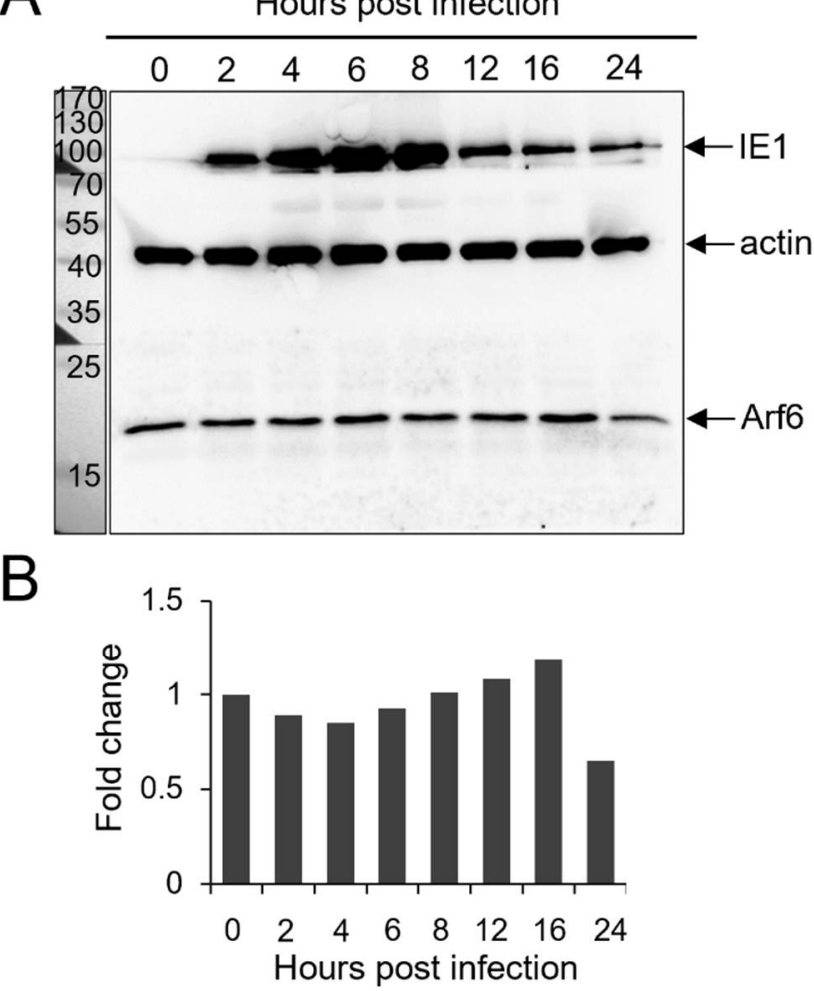

C MCMV infected -0 hpi
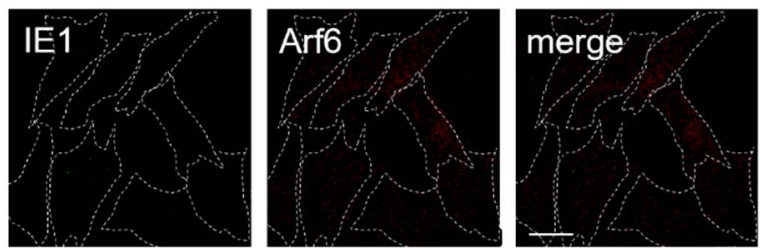

MCMV infected

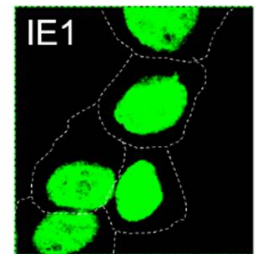

MCMV infected -1
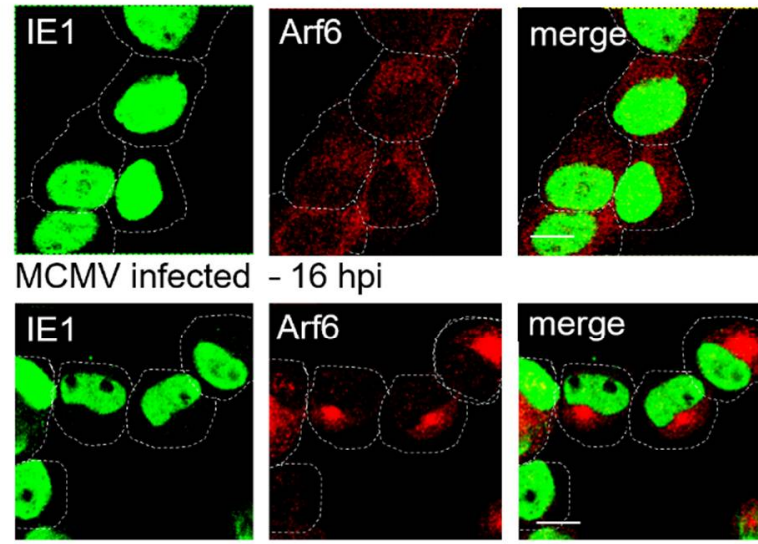

$-16 \mathrm{hpi}$
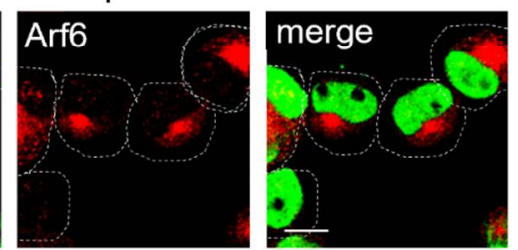

Figure 3. Expression levels of the class III Arf protein and its intracellular localization in the MCMV-infected cells during the early phase of infection. Balb 3T3 cells were infected with $\triangle \mathrm{m} 138-\mathrm{MCMV}$, and the expression level and intracellular recruitment of Arf6 in the early phase of MCMV infection (0-16 hpi) were analyzed by Western blot and immunofluorescence. Representative Western blots of Arf6 (A) expression in the early phase of MCMV infection are presented. Actin was used as a loading control, and IE1 expression was used as an infection control. Protein markers are shown on the left. (B) Quantitative analysis of Arf6 expression levels was performed as described in Materials and Methods. Results are expressed as a fold change relative to Arf6 expression in 0 hpi MCMV-infected cells. Immunofluorescence images of Arf6 (C) expression relative to the nuclear staining of immediate-early 1 (IE1) MCMV proteins during the early phase of infection. $\triangle \mathrm{m} 138-\mathrm{MCMV}$ infected Balb 3 T3 cells were fixed at 0, 6, and $16 \mathrm{hpi}$, permeabilized, and stained against IE1 and Arf6. The antibodies were visualized with the appropriate fluorochrome-conjugated non-crossreactive secondary reagents. Cell borders are indicated by dashed lines. Bars, $10 \mu \mathrm{m}$.

Altogether, the upregulation of the cellular levels of class I and class II Arf proteins and the different timings of Arf protein recruitment to the membranes of the pre-AC indicate the dynamic sequence of pre-AC membrane maturation and suggest that Arf proteins may be a crucial host cell factor in pre-AC biogenesis.

\subsection{All Arf Proteins Accumulate at the Membranes of the Inner Pre-AC, and Arf3 Also} Accumulates at the Membranes of the Outer Pre-AC

Considering that all Arf proteins accumulate in the pericentriolar area characteristic for the establishment of the pre-AC at the end of the early phase of MCMV infection (16 hpi), we next examined whether they are located in the outer or inner part of the pre-AC. Namely, our previous study demonstrated that the outer pre-AC is mainly composed of the rearranged Golgi stacks, whereas the inner pre-AC contains many membranous elements derived from EEs, the ERC, and the TGN $[6,7,12]$. To define Arf protein localization, we performed colocalization analysis of the Arf proteins in MCMV-infected cells that had been infected for $16 \mathrm{~h}$ with internalized transferrin receptors (TfRs), the cis-Golgi marker GM130, and the MCMV early protein $\mathrm{m} 06$. At $16 \mathrm{hpi}, \sim 60 \%$ of internalized TfR is retained in EEs 
and the rest is retained in the ERC [7], thereby accurately labelling EE- and ERC-derived membranous elements, which, together with TGN-derived membranous structures, build the bulk of the inner pre-AC [6,12]. The GM-130 labels relocated cis-Golgi membranes, which form the inner rim of the outer pre-AC [9-11], whereas the m06 protein is retained in the distal Golgi cisternae, mainly in the trans-Golgi $[60,61]$, and thereby is displayed on the outer rim of the outer pre-AC.

At $16 \mathrm{hpi}$, most of the internalized TfR accumulated in the perinuclear area of MCMVinfected cells (Figure 4A), consistent with our previous results [7,12,58]. The bulk of internalized TfRs compacted around the cell center in the juxtanuclear area. The rest remained in enlarged perinuclear endosomes, as demonstrated in the zoomed area box of the Arf1-stained sample in Figure 4B. The compacted TfRs highly overlapped with all of the Arf proteins, suggesting that all Arf proteins are recruited to the membranous elements of the inner pre-AC (Figure 4B). This resulted in approximately $60 \%$ pixel overlap between Arf1, Arf4, Arf5, and Arf6 and internalized TfR (Figure 4C and Figure S6A). In addition to the overlap of internalized TfR and Arf3 in the juxtanuclear area (Figure 4B), a significant fraction of Arf3 was displayed outside of this area in the form of a rim that did not show vacuolar appearance. This distribution resulted in the significantly decreased colocalization of Arf3 and internalized TfR to about 40\% (Figure 4C and Figure S6A). Similar results were observed when the Arf proteins were colocalized with the TGN marker Vti1a (Figure S1A). These data suggest that all Arf proteins accumulate at the membranes that form the inner pre-AC and that only Arf3 is substantially recruited at the membranes of the outer pre-AC.

To further examine the localization of Arf proteins in the outer pre-AC, we performed the colocalization of the Arf proteins and the GM130 on the Balb 3T3 cells infected with MCMV at 16 hpi (Figure 5). As expected from colocalization analysis with the TfRs, in MCMV-infected cells, Arf1, -4, -5, and -6 were mainly concentrated within the ring confined by GM130-positive membranes (Figure 5A). The overlaps between these Arfs and GM130 were only observed at the internal rims of GM130-labeled structures, resulting in $\sim 20-30 \%$ colocalization being identified by Mander's coefficient overlap (Figure 5B,C and Figure S6B). Given that colocalization was not observed in the outer areas of the GM130labeled structures, these overlaps are likely the result of a high compacting of internal and outer membranous elements of the pre-AC, which are identified as colocalization during 3D colocalization analysis. In contrast, a significant fraction of Arf3 ( 50\%) colocalized with GM130 (Figure 5C and Figure S6B), although Arf3 also localized in GM130 negative membranous compartments proximally to the cell nucleus and in the membranous structures outside of the GM130-confined ring, including the subplasmalemmal area (Figure 5A). These data suggest that the Arf1, Arf4, Arf5, and Arf6 proteins are mainly recruited to EE-, ERC-, and TGN-derived membranes within the inner pre-AC, whereas Arf3 is primarily recruited to the Golgi-derived membranes of the outer pre-AC. However, Arf3 is also recruited to the inner pre-AC and membranous system at the cell periphery.

To further explore the localization of Arf3, we performed colocalization analysis with the $\mathrm{m} 06$ protein, which accumulates at the distal Golgi compartments of MCMV-infected cells [61]. As expected, the minimal overlap between m06 and Arf1, Arf4, Arf5, and Arf6 could be observed (Figure 6A-C and Figure S6C). However, the outer pre-AC-associated Arf3 highly colocalized with m06 but not with Arf3 localized within the inner pre-AC and at the cell periphery (Figure 6A,B). These data indicate that Arf3 is highly recruited to the Golgi-derived membranes of the outer pre-AC. 
A
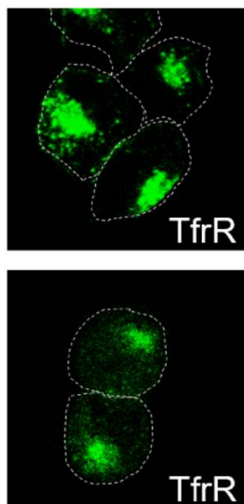

TfrR
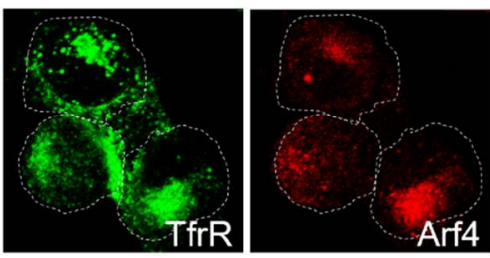

Arr3
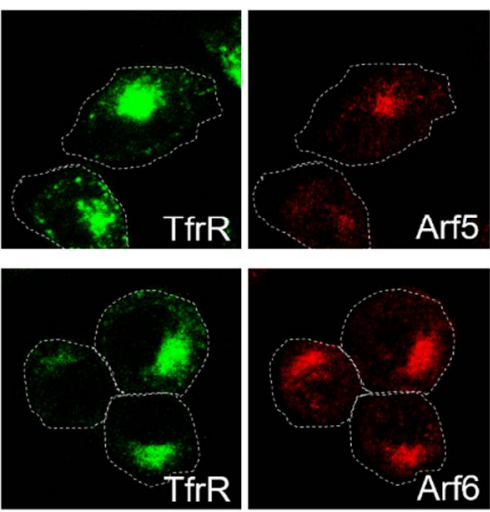

Arf6

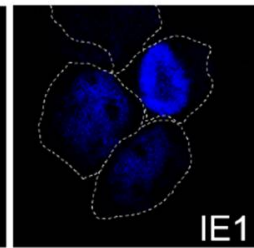

E1
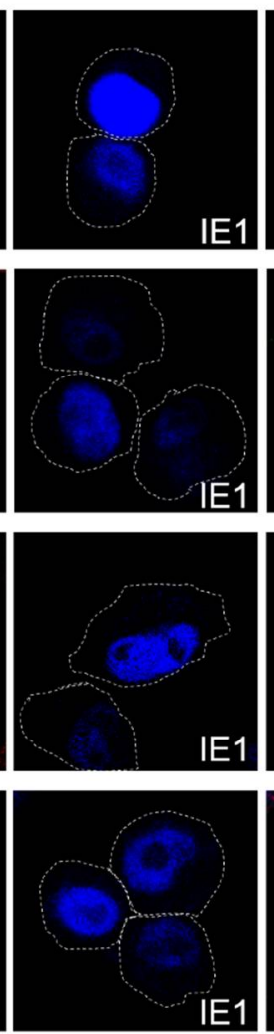

IE1
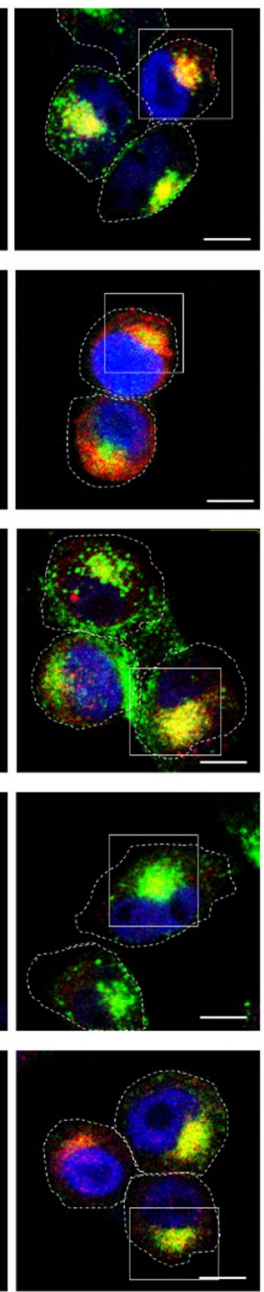

a.
B
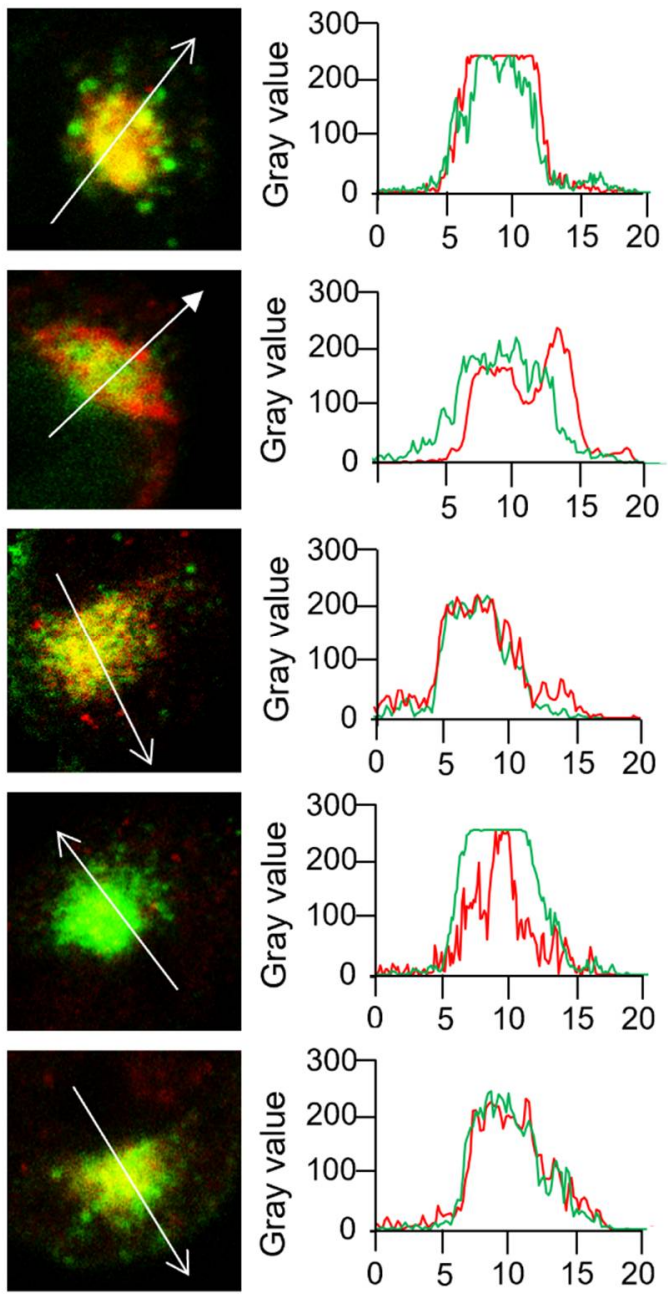

Distance in $\mu \mathrm{m}$

C

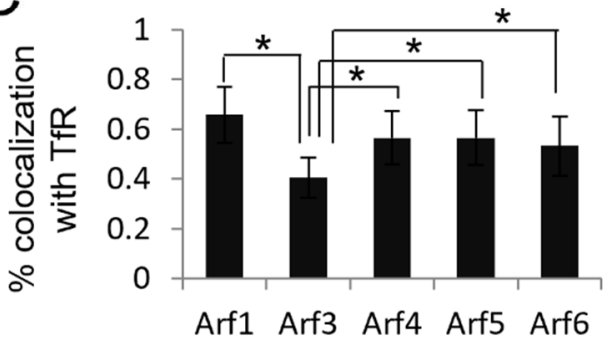

Figure 4. Arf proteins enriched within the inner part of the pre-AC. (A) At 15 hpi, $\Delta \mathrm{m} 138-\mathrm{MCMV}$-infected Balb $3 \mathrm{~T} 3$ cells were incubated $45 \mathrm{~min}$ with $\mathrm{Tf}-\mathrm{AF}^{488}$ at $37^{\circ} \mathrm{C}$ (green fluorescence), fixed, permeabilized, and stained against Arf proteins (red fluorescence) and IE1 (blue fluorescence). Triple-stained images are shown (focal plane across the mid-section of the cells). Fine dashed lines indicate cell borders. Full-lined boxes indicate the zoomed area. Bars, $10 \mu \mathrm{m}$. (B) Zoomed images were analyzed by plotting fluorescence intensity profiles along white arrow lines on the MaxEntropy threshold of the images. (C) Images were analyzed through the entire z-stack for colocalization using Mander's coefficients of pixel overlap. Data represent mean \pm STDEV per cell $(n=10-15)$. Asterisks indicate statistical significance $(*: p<0.005)$. 
A
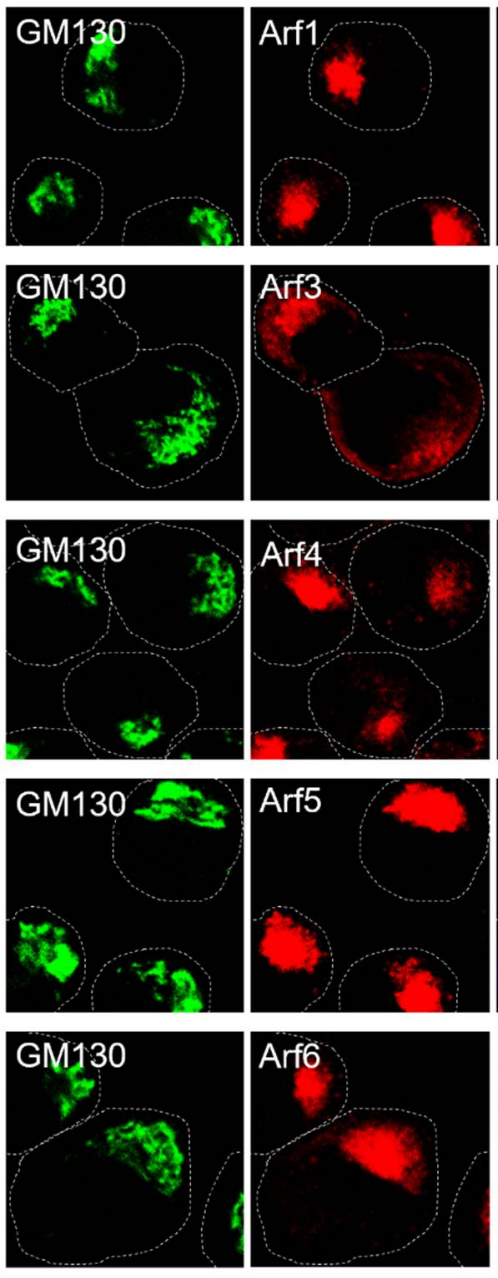

C

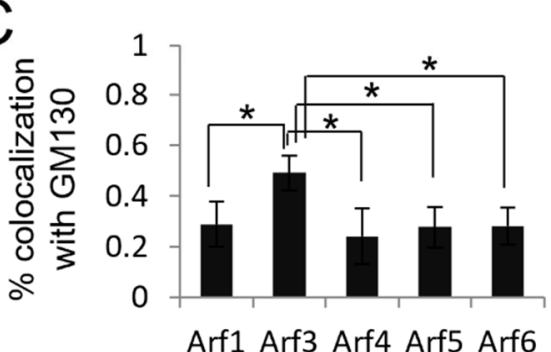

B
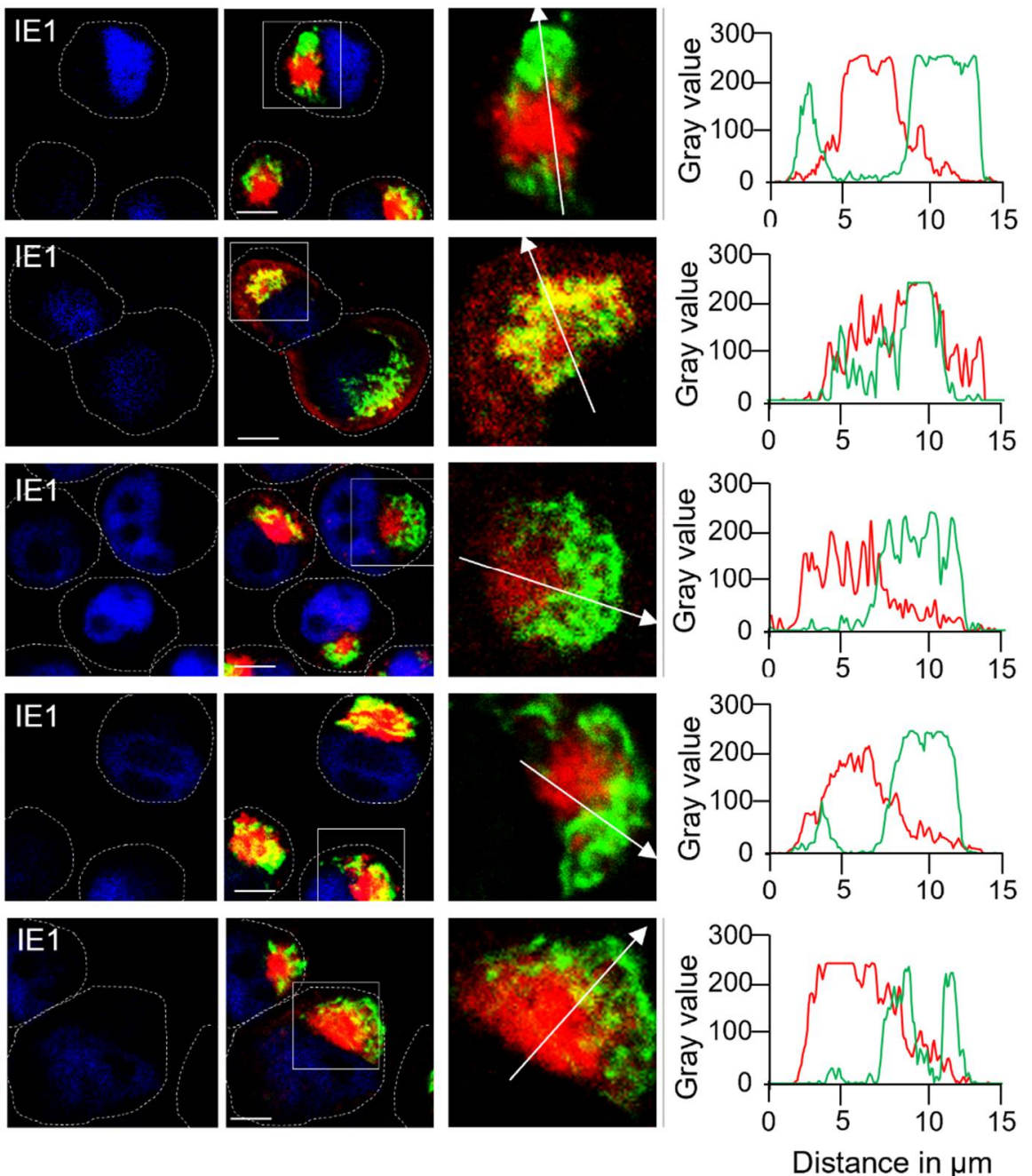

Figure 5. Arf proteins, except Arf3, are mainly excluded from the GM130-positive membraneous compartments of the pre-AC. (A) $\triangle$ m138-MCMV-infected Balb 3T3 cells were fixed at $16 \mathrm{hpi}$, permeabilized, and stained against Arf protein (red fluorescence), GM130 (green fluorescence), and IE1 (blue fluorescence). Focal planes across the mid-section of the cells are shown. Dashed lines indicate cell borders. Full-lined boxes indicate the zoomed area. Bars, $10 \mu \mathrm{m}$. (B) Zoomed images were analyzed by plotting fluorescence intensity profiles along white arrow lines on the MaxEntropy image threshold. (C) Images were analyzed through the entire z-stack for colocalization using Mander's coefficients of pixel overlap. Data represent mean \pm STDEV per cell $(n=10-14)$. Asterisks indicate statistical significance $\left(^{*}: p<0.005\right)$. 

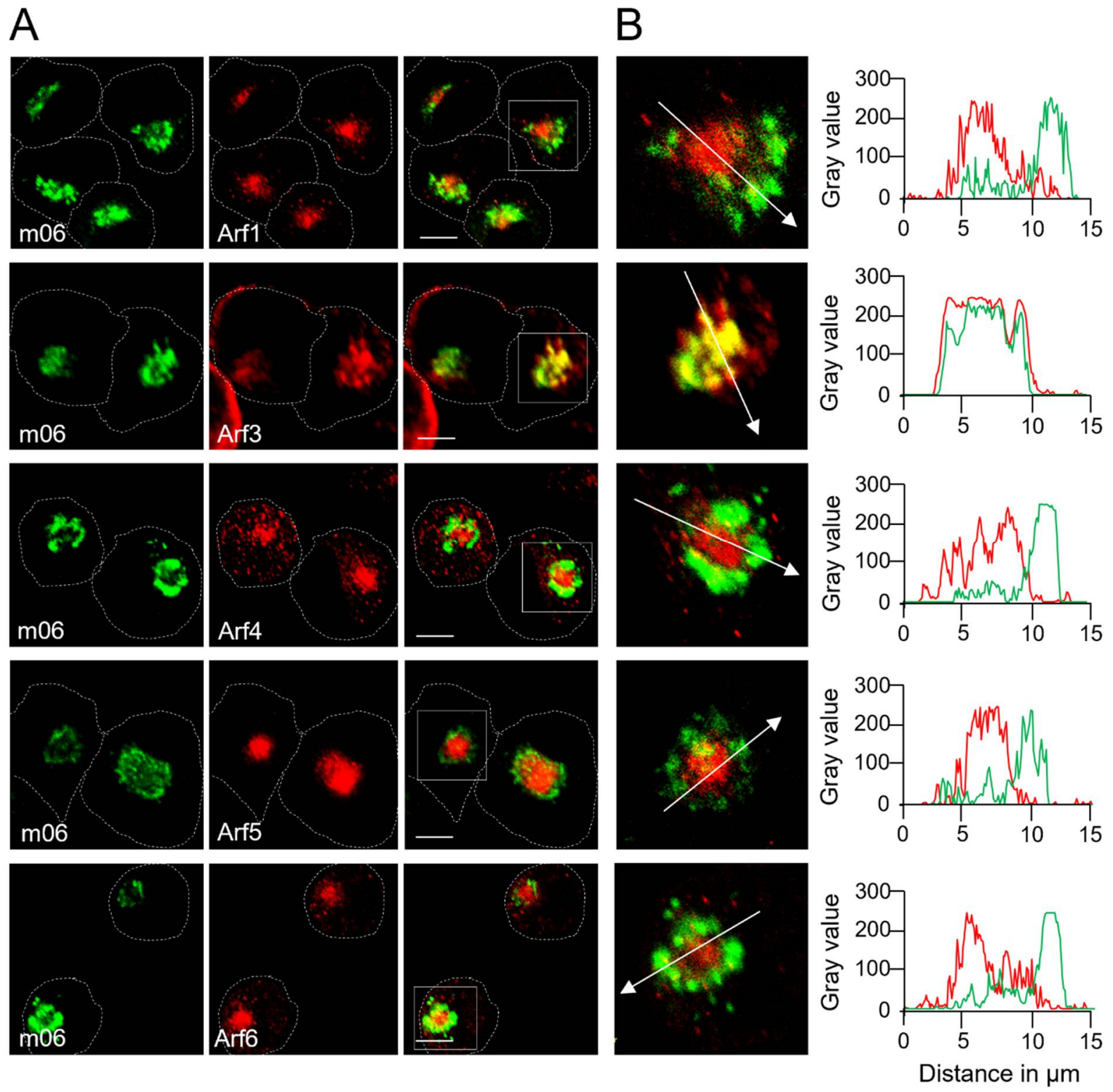

C

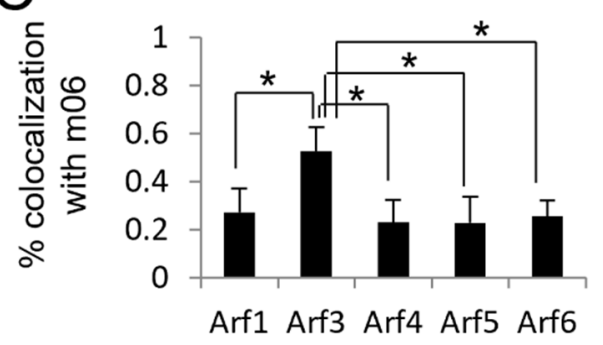

Figure 6. Arf3 protein is recruited to membranes of the trans-Golgi elements of the outer pre-AC. (A) $\triangle \mathrm{m} 138-\mathrm{MCMV}$ infected Balb 3T3 cells were fixed at $16 \mathrm{hpi}$, permeabilized, and stained against Arf protein (red fluorescence) and m06 (green fluorescence). Focal-plane images across the mid-section of the cells are shown. Dashed lines indicate cell borders. Full-lined boxes indicate the zoomed area. Bars, $10 \mu \mathrm{m}$. (B) Zoomed images were analyzed by plotting fluorescence intensity profiles along white arrow lines on the MaxEntropy threshold of images. (C) Images were analyzed through the entire z-stack for colocalization using Mander's coefficients of pixel overlap. Data represent mean \pm STDEV per cell $(n=10-13)$. Asterisks indicate statistical significance $\left.{ }^{*}: p<0.005\right)$. 


\subsection{Knockdown of Arf1, Arf3, Arf4, and Arf6 Prevents the Establishment of the Inner Pre-AC}

The first event in the formation of pre-AC that can be visualized by immunofluorescence microscopy is an accumulation of expanded EE-ERC-TGN membranes in the juxtanuclear region of the infected cells that represent the formation of the inner part of the pre-AC $[6,7,58]$. We have shown earlier that Rab10 is the most reliable marker of those earliest events because its signal is barely detectible in uninfected cells. In contrast, in $16 \mathrm{~h}$ MCMV-infected cells, Rab10 is accumulated in the juxtanuclear region and displays bright immunofluorescence staining, while other identified markers of pre-AC establishment are already present in that area in uninfected cells or accumulate there significantly in a later stages and therefore do not represent a tool for this study that is as reliable as Rab10 [6]. Therefore, to explore the significance of Arf proteins in the formation of pre-AC, we monitored the accumulation of Rab10 in the pericentriolar region of MCMV-infected cells in which the expression of Arf proteins was silenced by small interfering RNAs (siRNAs). The infection efficiency was monitored by the nuclear expression of the IE1 protein. The specificity and efficiency of siRNA silencing were quantitatively monitored by Western blot analysis in uninfected cells and by the immunofluorescence staining of the Arf proteins in the MCMV-infected cells. The optimized protocols of Arf silencing efficiently depleted Arf proteins $72 \mathrm{~h}$ after transfection (Figure 7 and Figures S2-S4), and very few Arf proteins could be detected in transfected cells $16 \mathrm{~h}$ after infection with MCMV (Figure S5). These data indicate that the optimized protocols for silencing specifically and efficiently deplete Arf proteins and that the observed upregulation mechanisms induced by MCMV infection cannot override the silencing effect.

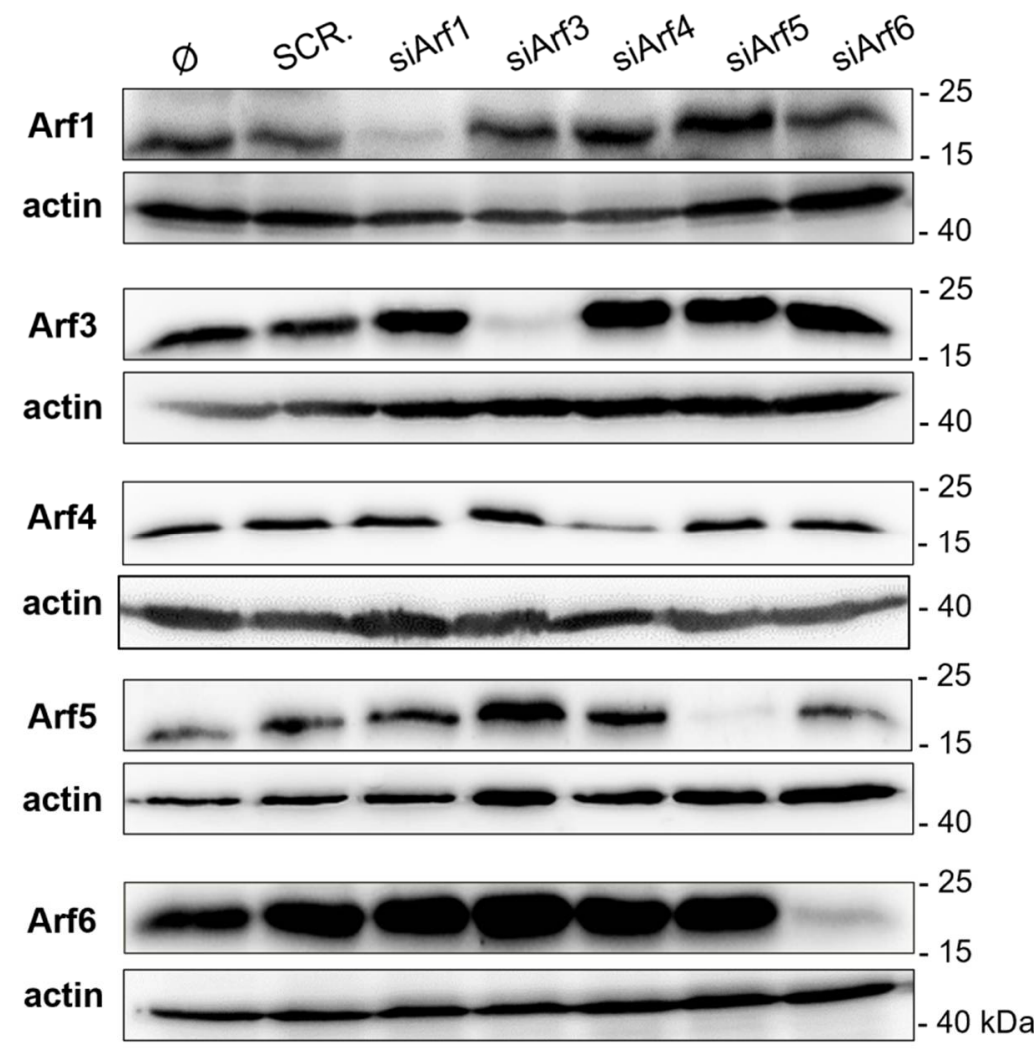

Figure 7. Efficiency and specificity of Arf1, Arf3, Arf4, Arf5, and Arf6 silencing. Balb 3 T3 cells were transfected with negative control scrambled siRNA (SCR.) or siRNAs targeting Arf proteins (siArf1-6). After $72 \mathrm{~h}$, cell lysates were analyzed by Western blot and stained with specific antibodies against Arf proteins. Actin was used as a loading control.

As expected, in the control scrambled siRNA-transfected (SCR.) and infected cells immediately after infection with $\triangle \mathrm{m} 138-\mathrm{MCMV}(0 \mathrm{hpi})$, no cells positive for IE1 were detected, and Rab10 staining showed faint dispersed cytoplasmatic signal without jux- 
tanuclear accumulation (Figure 8). The same was observed in untransfected cells and cells transfected with siRNA targeting Arf proteins (siArf1-6) [62].

A
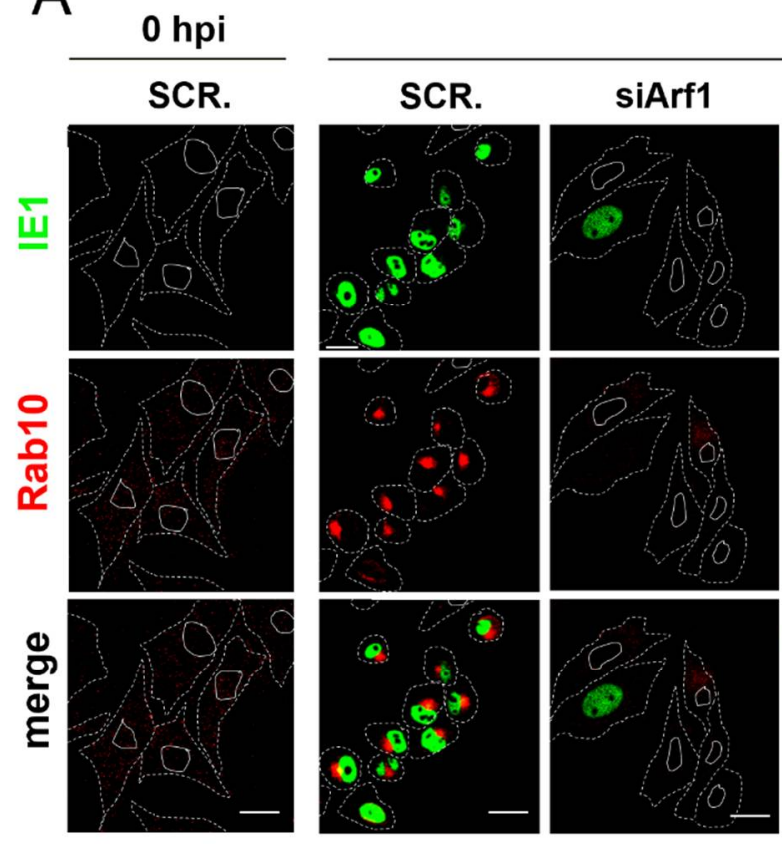

\section{$16 \mathrm{hpi}$}
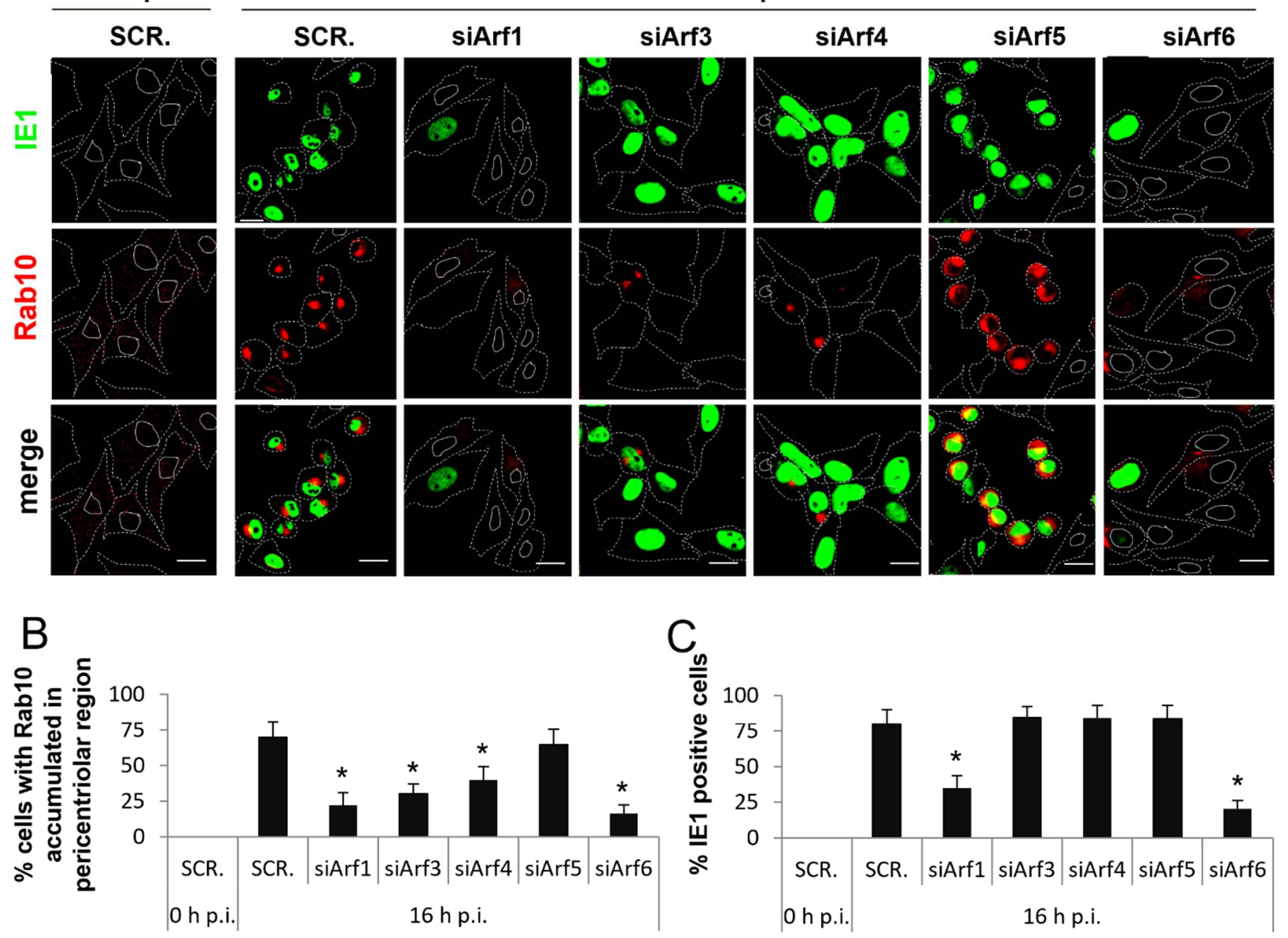

Figure 8. Knockdown of Arf1, Arf3, Arf4, and Arf6 prevents the development of the pre-AC. (A) Balb 3T3 cells were transfected with negative control scrambled siRNA (SCR.) or siRNAs targeting Arf1-6 (siArf1-6) and after $72 \mathrm{~h}$ infected with $\triangle \mathrm{m} 138-\mathrm{MCMV}$. At 0 and $16 \mathrm{hpi}$, cells were fixed, permeabilized, and stained against Rab10 (red fluorescence) and IE1 (green fluorescence). Cell borders are indicated by dashed and nuclei by full lines. Representative images with focal planes across the mid-section of the cells are shown. Bars, $20 \mu \mathrm{m}$. Percentages of cells with the juxtanuclear Rab10 accumulation (B) and nuclear IE1 expressions (C) were determined as described in Materials and Methods, and data are presented as the mean \pm STDEV. Asterisks above error bars indicate statistical significance $\left({ }^{*}: p<0.005\right)$ when compared to the control (SCR.).

At $16 \mathrm{hpi}$, in cells transfected with SCR. siRNA, 70\% of the analyzed cells rounded, accumulated Rab10 in the juxtanuclear region, and expressed bright nuclear staining of IE1 (Figure 8A). Quantification of Rab10 and IE1 expressing cells demonstrated $69 \pm 14 \%$ of cells with Rab10 juxtanuclear accumulation (Figure 8B and Figure S7A) versus $80 \pm 12 \%$ of IE1 expressing cells (Figure 8C and Figure S7B), indicating that the majority of transfected and infected cells developed the inner pre-AC at $16 \mathrm{hpi}$. This result is similar to that observed in untransfected cells under the same experimental settings, indicating that transfection conditions do not alter the membranous organelle reorganization program in MCMV-infected cells (Figure S1B).

Similar to SCR. siRNA-transfected cells, Arf5 knockdown cells (Figure 8A-C) rounded, accumulated Rab10 in the juxtanuclear region (62 $\pm 7 \%$ of cells), and expressed IE1 
( $84 \pm 8 \%$ of cells) at $16 \mathrm{hpi}$. These data indicate that most infected cells undergo the development of the inner pre-AC in the absence of Arf5. In contrast, cells transfected with siArf1, siArf3, siArf4, and siArf6, displayed a lack of cell rounding and significantly reduced the juxtanuclear accumulation of Rab10 (Figure 8A). At 16 hpi, the Rab10 accumulation was observed in $22 \pm 12,30 \pm 7,41 \pm 10$, and $16 \pm 8 \%$ of the analyzed cells transfected with siArf1, siArf3, siArf4, and siArf6, respectively, which was significantly lower than the control (SCR.) cells (Figure 8B and Figure S7A). However, the ratio of diminished Rab10 accumulation and the expression of IE1 was different among cells with depleted Arf proteins. Although the accumulation of Rab10 was significantly inhibited in siArf3and siArf4-transfected cells at 16 hpi (Figure 8A,B and Figure S7A), the establishment of infection as monitored by the nuclear expression of the IE1 protein was not impaired. Namely, $86 \pm 6 \%$ of the siArf3 and $85 \pm 11 \%$ of the siArf4-transfected cells were positive for IE1, similar to that observed in the control cells transfected with scrambled siRNA (SCR.) and siArf5-transfected cells (Figure 8C and Figure S7B). However, most of Arf3- and Arf4-depleted cells did not display the cell rounding phenotype (Figure 8A), indicating that Arf3- and Arf4-dependent membranous organelle reorganization within the inner pre-AC are associated with cytopathogenic events related to cytoskeleton rearrangements. In contrast, siArf1 and siArf6-transfected cells (Figure 8A-C and Figure S7A,B), in addition to an almost complete absence of the juxtanuclear accumulation of Rab10, displayed a lack of cell rounding but also a significant decrease in IE1 expression (35 \pm 9 and $20 \pm 5 \%$ positive cells, respectively). These data suggest that both Arf1 and Arf6 are essential for the earlier events in the MCMV replication cycle that occurs during the establishment of infection and before the expression of IE genes.

\subsection{Knockdown of Arf1 and Arf6 Abolishes the Establishment of MCMV Infection}

To further examine the contribution of Arf proteins in the establishment of MCMV infection, cells transfected with control scrambled siRNA (SCR.) or siRNA targeting specific Arf proteins (siArfs) were infected and at $16 \mathrm{hpi}$ and were stained for the expression of the IE1 and m06 proteins. IE1 was expressed within the first hour of infection in the cell nucleus, whereas $\mathrm{m} 06$ was also expressed before the initiation of pre- $\mathrm{AC}$ formation after 2-3 hpi, but it was localized in the Golgi apparatus that would form the outer part of established pre-AC $[60,61]$. As expected, the percentage of cells expressing the IE1 and m06 proteins was similar in control cells (SCR.) and Arf3-, Arf4-, and Arf5-depleted cells (Figure 9A,B and Figure S7C), indicating normal progression of the immediate-early and early phases of infection in these cells. However, the percentage of IE1 and m06 expressing cells was significantly reduced in Arf1-depleted cells and almost completely abolished in Arf6-depleted cells (Figure 9A,B and Figure S7C). This observation was further confirmed by a more sensitive assay: through the infection of cells with the C3X-MCMV (Figure 9C), a recombinant virus generated on the wild-type background by the insertion of a GFP (green fluorescent protein) cassette under the control of the major immediateearly HCMV promoter in front of ie2 gene [55]. After infection with this virus, $\sim 68 \%$ of control cells (transfected with scrambled siRNA) were positive for green fluorescence at $16 \mathrm{hpi}$, as demonstrated by flow cytometric quantification (Figure 9C). In contrast, the green fluorescence signal was only detected in $~ 37 \%$ of siArf1-transfected cells and in $~ 24 \%$ of siArf6-transfected cells. These data confirm our observations from immunofluorescence staining and suggest that Arf1 and Arf6 depletion prevent entry into the immediate-early phase of MCMV gene expression. The fluorescence intensity of GFP expression in siArf1and siArf6-transfected cells was significantly reduced compared to the fluorescence signal of control cells, indicating that Arf1 and Arf6 depletion significantly reduced the load of the viral genome in the nucleus. This resulted in the drastically reduced expression of IE1 and the almost abolished expression of $\mathrm{m} 06$, as demonstrated by Western blot analysis (Figure 10). Altogether, these data suggest that Arf1 and Arf6 are essential for the establishment of infection in the steps before the MCMV genome enters into the nucleus. 


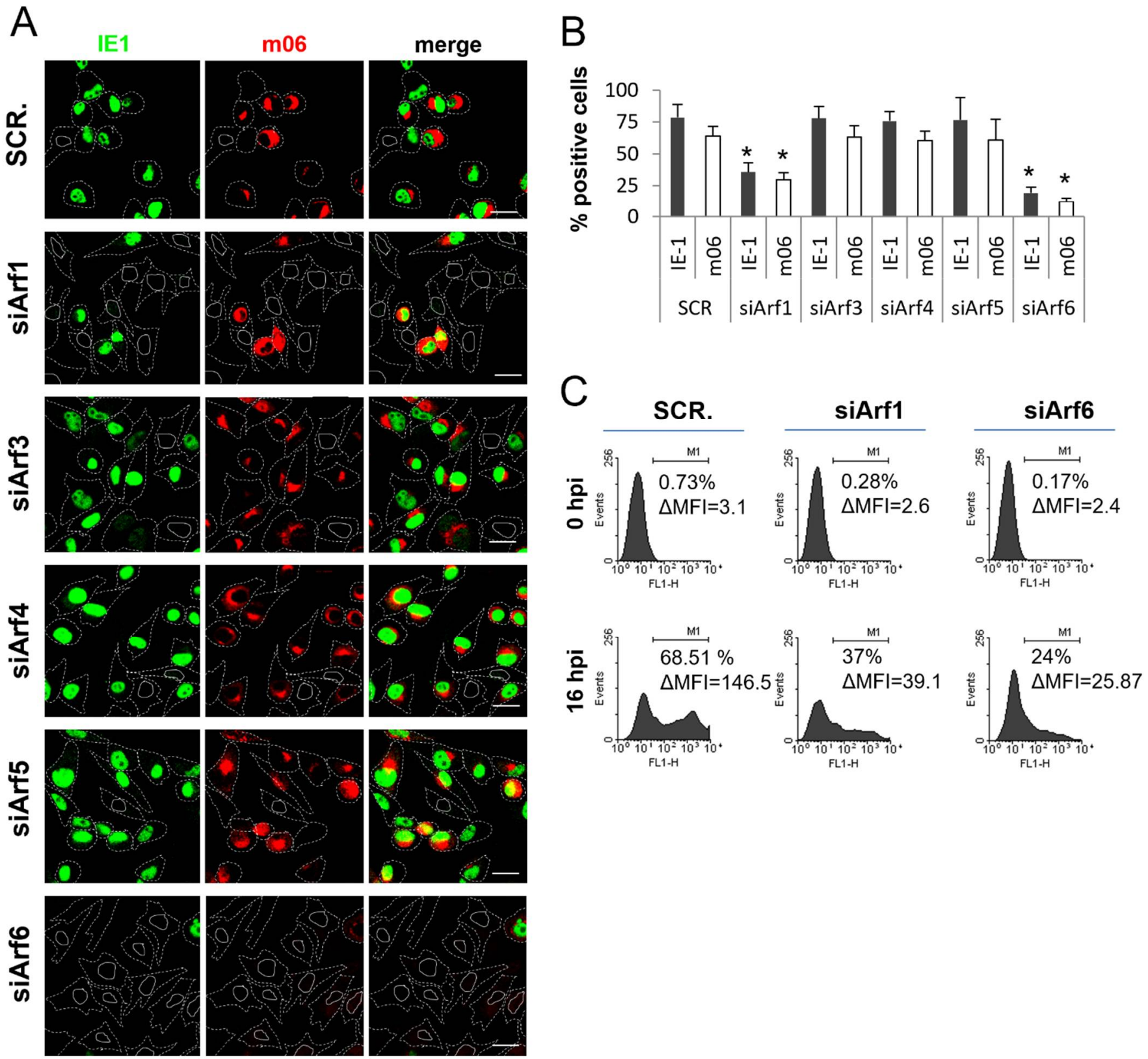

Figure 9. Knockdown of Arf1 and Arf6 inhibits the establishment of MCMV infection. (A) Balb3T3 cells were transfected with negative control scrambled siRNA (SCR.) or siRNAs targeting Arf1-6(siArf1-6) and after $72 \mathrm{~h}$ infected with $\Delta \mathrm{m} 138$ MCMV. At 16 hpi, cells were fixed, permeabilized, and stained against m06 (red fluorescence) and IE1 (green fluorescence). Cell borders are indicated by dashed lines and nuclei by full lines. Representative images with focal planes across the mid-section of the cells are shown. Bars, $20 \mu \mathrm{m}$. (B) The percentage of IE1 and m06 positive cells was determined as described in Materials and Methods. Data represent mean \pm STDEV, and asterisks above error bars indicate statistical significance (*: $p<0.005)$ when compared to the control (SCR.). (C) Balb 3T3 cells transfected with scrambled siRNA (SCR.), siArf1, or siArf6 were infected with C3X-GFP MCMV $72 \mathrm{~h}$ after transfection, and at 0 and 16 hpi, the GFP fluorescent signal was analyzed by flow cytometry. A representative of three independent experiments is shown. 

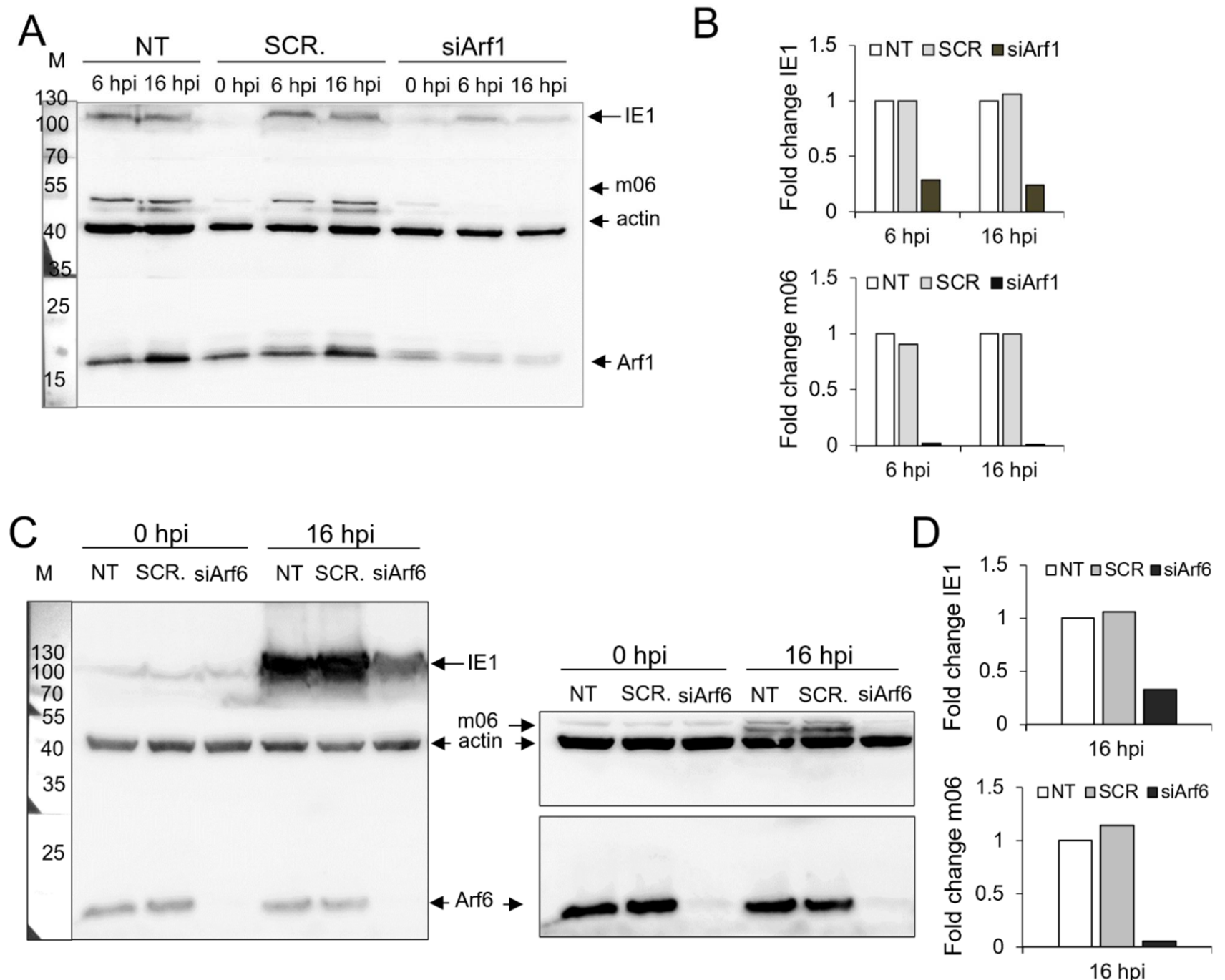

Figure 10. Arf1 and Arf6 are essential for the establishment of MCMV infection. (A) Untransfected (NT), scrambled siRNA(SCR.), or siRNA targeting Arf1- (siArf1) transfected Balb 3T3 cells were infected with $\triangle \mathrm{m} 138$-MCMV $72 \mathrm{~h}$ after transfection. At 0,6 , and $16 \mathrm{hpi}$, the expression of IE1 and m06 was analyzed by Western blot. Actin was used as a loading control, and Arf1 expression was used as a silencing efficiency control. A representative experiment is shown. (B) Quantitative analysis of IE1 and m06 expression levels in NT, SCR.-, and siArf1-transfected cells at 0, 6, and 16 hpi was performed as described in Materials and Methods. Results are expressed as a fold change relative to IE1 or m06 expression in NT cells at the same time of infection. (C) NT, SCR.-, or siArf6-transfected Balb 3T3 cells were infected with $\Delta$ m138-MCMV $72 \mathrm{~h}$ after transfection, and at 0 and $16 \mathrm{hpi}$, the expression of IE1 and m06 was analyzed by Western blot. Actin was used as a loading control, and Arf6 expression was used as a silencing effiency control. The right panel represents WB signals after additional staining with the anti-m06 antibody and at longer exposures. A representative experiment is shown. (D) Quantitative analysis of IE1 and m06 expression levels in NT, SCR-., and siArf6-transfected cells at 0 and 16 hpi was performed as described in Materials and Methods. Results are expressed as a fold change relative to IE1 or m06 expression in NT cells at the same time of infection.

\section{Discussion}

This study explored the role of Arf proteins in the biogenesis of pre-AC in MCMVinfected cells. We have shown that already in the early phase of infection, MCMV massively reorganizes the Arf system and increases the levels of class I and class II Arf proteins (Figures $1 \mathrm{~A}, \mathrm{~B}, \mathrm{D}, \mathrm{E}$ and $2 \mathrm{~A}, \mathrm{~B}, \mathrm{D}, \mathrm{F}$ ) and leads to accumulation of all Arfs in the perinuclear area of infected cells (Figures 1C,F, 2C,F and 3C). The perinuclear expansion is apparent at $6 \mathrm{hpi}$, which corresponds with the development of the pre-AC. All Arf proteins are accumulated in the inner area of the pre-AC confined by the outer Golgi stacks and rich in 
EE/ERC/TGN membranous elements [7-12] (Figure 4), indicating that MCMV infection dysregulates Arf recruitment cascades at EE-, ERC-, and TGN-derived membranes. Arf3 is also recruited to membranes of the Golgi in the outer pre-AC (Figures 5 and 6). The recruitment is not synchronous, indicating the sequential dysregulation of the Arf system in the membranous organelle reorganization representing the establishment of the pre-AC. The accumulation of the class I Arfs (Arf1 and Arf3) is evident at 6 hpi, whereas class II and class III Arfs are recruited later. Knockdown experiments, using siRNAs, demonstrated the requirement of Arf1, Arf3, Arf4, and Arf6 for the establishment of pre-AC, as displayed by the accumulation of Rab10 in the juxtanuclear area of the infected cell (Figure 8). However, knockdown of Arf1 and Arf6 affected the earlier stages of infection, prior expression of MCMV immediate early genes (Figures 9 and 10), indicating that they are essential for virus entry or transport to the cell nucleus. Thus, although these Arfs may contribute to the membranous organelle reorganization during pre-AC formation, their direct role in those processes cannot be revealed by knockdown experiments. However, Arf3 and Arf4 knockdown prevented the accumulation of Rab10 in the pericentriolar area of MCMVinfected cells without an evident effect on the establishment of infection and MCMV immediate-early and early gene expression, suggesting their important role in regulating membrane dynamics during pre-AC development.

In uninfected and MCMV-infected Balb 3T3 cells at 0 hpi, immunofluorescence staining of endogenous Arf proteins did not display larger membranous organelles but rather small punctate cytoplasmic structures. This is consistent with their fast turnover at the membranous organelles and aligns with the previously reported data obtained in uninfected cells $[63,64]$. However, in cells infected with MCMV, the immunofluorescence staining resulted in the bright signal of all of the Arf proteins in the perinuclear area of the cell. The bright staining of the class I Arfs was evident at $6 \mathrm{hpi}$, whereas class II and III Arfs were displayed later, as demonstrated by staining at $16 \mathrm{hpi}$. Even though WBs showed significantly increased levels of class I and class II Arfs already at $6 \mathrm{hpi}$, in contrast to the class I Arfs, at 6 hpi the IF staining of Arf4, and especially that of Arf5, was still weak. This is most likely due to their dispersion in the cytoplasm and the lack of their recruitment and accumulation in the pericentriolar area of MCMV-infected cells at $6 \mathrm{hpi}$. This conclusion is supported by a significant difference in Arf6 IF staining at $6 \mathrm{hpi}$ and $16 \mathrm{hpi}$, although Arf6 levels did not significantly change throughout the early phase of MCMV infection.

Although we cannot determine the exact mechanism of Arfs accumulation at the moment, given that the inner pre-AC and AC mainly contain membranous elements derived from the EE, ERC, and TGN $[7,9,10,12]$ and that the outer pre-AC is composed of Golgi stacks, the accumulation of all Arf proteins within the inner pre-AC and the additional recruitment of the Arf3 to the outer pre-AC indicates the massive dysregulation of regulatory loops that control their membrane recruitment. Namely, class I Arfs, Arf1, and Arf3, can be activated at the PM [31,65], EEs [66], the ERC [24,67], and the TGN [17,30]. Arf1 is also associated with the early Golgi [68], whereas Arf3 is associate with the late Golgi [14]. Class II Arfs can be activated at the TGN [69,70], the ERC [25,67], and ERGolgi intermediate compartment [71]. Arf5 can also be activated at the PM [72]. The class III member Arf6 acts in the feedback axis with Rab35 at the PM [17,65], and the ERC $[73,74]$ and regulates several endocytosis- and exocytosis-related processes within the cell $[17,75-77]$. The regulatory loops that control Arf membrane recruitment are based on the activities of GEFs, cellular proteins that activate the Arfs and facilitate their recruitment to membranes, and GAPs, which dephosphorylate GTP on activated Arfs and thereby initiate their de-recruitment from membranes and their dispersion into the cytosol. Thus, MCMV infection may dysregulate the recruitment of either Arf GEFs or GAPs and thereby cause Arf accumulation at the EE-, ERC-, and TGN-derived membranes within the pre-AC and the accumulation of Arf3 at Golgi membranes that surround the inner pre-AC. Our previous study [6] demonstrated the recruitment of several Arf GEFs within the AC of MCMV-infected cells, suggesting that MCMV infections affect the processes before GEF recruitment. However, the regulatory loops within the Arf system are more complex and 
not only involve more Arf GEFs and GAPs but also members of the Arl subfamily; thus, an additional systematic study of the Arf regulatory loop recruitment in MCMV-infected cells is required. This study is currently underway in our laboratory.

By recruiting different effector proteins, Arfs control the transport through the entire endosomal system and the TGN $[14,17,24,25,67,78,79]$, whose membrane elements form the inner part of the pre-AC and the AC in the later stages of infection $[6,7,9,10]$. Arfs are also important for maintaining the structure and function of the Golgi apparatus $[11,27,68,71,78,80]$, whose stacks form the outer pre-AC but retain their basic functions, such as the loading and processing of the MCMV-encoded nonstructural protein $\mathrm{m} 06$ and the viral glycoproteins in the late phase of infection [6,7,11]. The recruitment of Arf effectors at membranes depends on the duration of the Arf GTP binding/hydrolysis cycle [14,81]. The accumulation of the Arfs on the membranes of intracellular compartments leads to their expansion and massive accumulation of cargo molecules within them $[19,35,41,67]$. Therefore, the recruitment of Arf proteins to the inner pre-AC could be one of the reasons for the reorganization and accumulation of the expanded membranous elements of the EE, ERC, and EE-ERC interface in the pericentriolar region of MCMV-infected cells and are therefore important for the biogenesis of pre-AC. Although the activation and recruitment of Arf GTPases on replication organelles have been reported after infection with different viruses [82-88], their importance in the biogenesis of pre-AC in MCMV-infected cells is understudied.

To address the requirements of Arf proteins in the biogenesis of pre-AC in MCMVinfected cells, we monitored Rab10 accumulation after Arf protein knockdown. We used Rab10 as a readout because of the adverse difference of the immunofluorescence Rab10 signal in uninfected and MCMV-infected Balb 3T3 cells. In uninfected Balb 3T3 cells, the Rab10 signal was barely detectable, which is likely due to a high turnover of Rab10 at membranes, as reported for Madin-Darby Canine Kidney (MDCK) epithelial cells [89]. However, in MCMV-infected cells, Rab10 accumulates in the juxtanuclear area of $\sim 90 \%$ of MCMV-infected cells and can be recorded as the earliest and the most reliable event of pre-AC establishment by immunofluorescence studies [6]. The Rab10 accumulation was drastically reduced in Arf1, Arf3, Arf4, or Arf6 knockdown cells, demonstrating the contribution of these Arfs in the biogenesis of the pre-AC. Surprisingly, although Arf5 accumulated at the membranes of the inner pre-AC, it seems that it is not crucial for pre-AC biogenesis. This does not necessarily mean that it is not involved in the formation of pre-AC. It could be that its function is replaceable in Arf5 knockdown Balb 3T3 cells. On the other hand, since in most cases Arf GEFs are not exclusive activators of individual Arfs [20,27], it is also possible that its accumulation is a side effect of the accumulation of Arf GEFs intended for activation of some other Arf protein.

Besides a drastic reduction of Rab10 accumulation, Arf1 and Arf6 knockdowns were associated with decreased immediate-early (IE1) and early (m06) gene expression in MCMV-infected cells, suggesting that Arf1 and Arf6 act at the earliest stages and are essential for the establishment of MCMV infection. These Arfs act at the PM and thus may influence virus attachment to the cell surface, virus entry, and endosomal transport to the cell nucleus or may influence the unpackaging and integrating of the virus genome into the nucleus. Over the years, several PM proteins have been reported to function as CMV receptors with docking or entry-mediating properties, including heparan sulfate proteoglycans, EGFR [90], PDGFR $\alpha$ [91-93], integrins [94], Nrp2, CD147 [95-98], MHC-I molecules [99], CD90 [100], CD147 and CD151 [101]. Thus, the disruption of their endocytic trafficking would alter the virus entry. At the PM, Arf1 and Arf6 regulate both the clathrindependent and -independent endocytosis of different cargo molecules, including molecules identified to serve as CMV receptors, such as receptor tyrosine kinases such as PDGFR and EGFR [31,102], integrins [17,90], CD147 [43,81], MHC class I molecules [26,42,103], and GPIanchored proteins such as CD90 and CD151 [31]. Thus, it is likely that the lack of Arf1 or Arf6 can interrupt the PM-associated processes of MCMV pathogenesis, especially because functions of Arf1 and Arf6 are not reported to be directly linked to the cell nucleus. The role of Arf6 in viral entry was reported for HIV-1 [104,105], Coxsackievirus A9 [106], Vaccinia 
viruses [107], and Epstein-Barr virus [108] infection, although reported mechanisms might not apply to every infected cell [109].

In cells lacking Arf3 or Arf4, expression of immediate early (IE1) and early (m06) viral proteins was not impaired (Figures 8 and 9), suggesting the regular establishment of MCMV infection. Even more, the fluorescence intensity of GFP expression in siArf3 and siArf4-transfected and C3X-MCMV-infected cells was not significantly changed, compared to the fluorescence signal of the control cells (Supplementary Figure S9), indicating that Arf3 and Arf4 depletion does not influence the load of the viral genome in the nucleus. However, Arf3 and Arf4 knockdown cells failed to accumulate Rab10 in the juxtanuclear region (Figures 8 and 9 ) and to establish pre-AC. Although the exact mechanisms by which Arf3 and Arf4 affect the biogenesis of pre-AC have yet to be elucidated, one of the possible mechanisms could be related to the organization of the microtubular network. A recent report demonstrates that cytoskeletal rearrangement and destabilization of microtubules may be an essential step in the pre-AC biogenesis [110]. Since only slight cell rounding was observed in Arf3 and Arf4 knockdown cells (Figures 8 and 9), it is possible that the activity of Arf3 and Arf4 is associated with processes that influence the destabilization of the microtubular network in MCMV-infected cells during the formation of the pre-AC and that Arf3 and Arf4 knockdowns prevent the destabilization of the microtubules, which, in turn, blocks the formation of the pre-AC. Another possibility is an indirect contribution of Arf4 in pre-AC biogenesis. In uninfected cells, activated Arf1 is mainly found on the Golgi membranes, and its function is related to the linking and maintaining of the structure of the Golgi [111-113], while it is not essential for the cis-Golgi association of GM130 [114]. However, it was also shown that activated Arf4 facilitates the recruitment of the Arf1 GEFs Big1 and Big2 $[27,115,116]$ to the TGN and consequently increases the activation of Arf1 on the TGN membranes [70]. Thus, the recruitment of Arf4 on the inner pre-AC membranes during MCMV infection could be a reason for the increased recruitment of Arf1 to the TGN and the reduced activation of Arf1 on the Golgi membranes that could have an influence on Golgi unlinking, one of the steps of pre-AC formation [6,7,11,12]. Thus, in cells lacking Arf4, the activation of Arf1 on the Golgi membranes would be less reduced, which could impair Golgi unlinking and pre-AC establishment.

In conclusion, our study demonstrates a significant role of Arf1, Arf3, Arf4, and Arf6 in the pathogenesis of CMV infection and host cell reorganization during the early phase of infection. Our study identifies at least Arf3 and Arf4 as required factors in the membranous organelle rearrangement during the establishment of the pre-AC. Arf1 and Arf6 may be also important players in this process. However, they substantially contribute to the earlier processes, and therefore, their direct role in the reorganization of the membrane dynamics associated with pre-AC formation cannot be demonstrated by knockdown experiments, which is an obstacle often associated with research on the role of host cell factors during viral infection.

\section{Conclusions}

Our study demonstrated increased levels of class I and II Arf proteins in the early phase of MCMV infection, the accumulation of all Arfs at the membranes of the pre-AC, and the requirement of Arf1, Arf3, Arf4, and Arf6 for the development of the MCMV pre-AC. However, our study also revealed that the contribution of Arf1 and Arf6 is most likely associated with the earliest stages of infection, either in terms of virion entry or the establishment of infection. Given that many processes of the AC biogenesis are conserved among beta-herpesviruses, our data may contribute to understanding the biogenesis of the HCMV assembly compartment and identifying host cell processes that may be targeted for the development of antivirals.

Supplementary Materials: The following are available online at https: / / www.mdpi.com/article/ 10.3390/life11080867/s1, Figure S1: Colocalization of Arf proteins with Vti1a, inner pre-AC marker, and pre-AC development in untransfected cells; Figure S2: Original raw blots and unedited ECL images used as a representative Western blot in Figure 7 of the manuscript; Figure S3: Original raw 
blots and unedited ECL images used as a representative Western blot in Figure 7 of the manuscript; Figure S4: Original raw blots and unedited ECL images used as a representative Western blot in Figure 7 of the manuscript; Figure S5: The efficiency of Arf1, Arf3, Arf4, Arf5, and Arf6 silencing in immunofluorescence experiments.; Figure S6: Individual data used for the calculation of mean \pm STDEV in colocalization analysis; Figure S7: Individual data used for the calculation of the mean \pm STDEV in immunofluorescence knockdown experiments. Figure S8: Quantification and statistics of Arfs expression levels in the early phase of MCMV infection determined by Western blot analysis; Figure S9: Flow cytometry analysis of GFP fluorescent signal in Balb 3T3 cells transfected with scrambled siRNA (SCR.), siArf3, or siArf4, and infected with C3X-GFP MCMV (0 and 16 hpi); Figure S10: Western blot analysis of IE1 and m06 expression at 0, 6, and $16 \mathrm{hpi}$ in untransfected, SCR.- or Arf1-transfected Balb 3T3 cells.

Author Contributions: Conceptualization, P.L. and G.B.Z.; methodology, V.P., H.M.L., G.B.Z. and P.L.; validation, V.P., H.M.L., G.B.Z. and P.L.; formal analysis, V.P., G.B.Z. and P.L.; investigation, V.P. and G.B.Z.; resources, G.B.Z., P.L. and H.M.L.; data curation, V.P. and G.B.Z.; writing-original draft preparation, G.B.Z.; writing—review and editing, G.B.Z., P.L., V.P. and H.M.L.; visualization, G.B.Z. and P.L.; supervision, G.B.Z. and P.L.; project administration, G.B.Z., P.L. and H.M.L.; funding acquisition, G.B.Z., P.L. and H.M.L. All authors have read and agreed to the published version of the manuscript.

Funding: This research was funded by Hrvatska Zaklada za Znanost (grant IP-2019-4-3582 to P.L., and grant IP-2020-02-1323 to G.B.Z.) and by the University of Rijeka (grants uniri-biomed-18-229 to G.B.Z., uniri-biomed-18-88 to P.L., and uniri-biomed-18-180 to H.M.L.).

Institutional Review Board Statement: Not applicable.

Informed Consent Statement: Not applicable.

Data Availability Statement: The data presented in this study are available upon request from the corresponding author.

Acknowledgments: The authors thank Igor Štimac, Ksenija Tulić, and Tatjana Daka for their technical assistance. We also thank Stipan Jonjić (University of Rijeka Faculty of Medicine) for the academic support and access to resources.

Conflicts of Interest: The authors declare no conflict of interest. The funders had no role in the design of the study; in the collection, analyses, or interpretation of data; in the writing of the manuscript, or in the decision to publish the results.

\section{References}

1. Choi, J.A.; Kim, J.-E.; Noh, S.-J.; Kyoung Kim, E.; Park, C.K.; Paik, S.-Y. Enhanced cytomegalovirus infection in human trabecular meshwork cells and its implication in glaucoma pathogenesis. Sci. Rep. 2017, 7, 43349. [CrossRef] [PubMed]

2. Emery, V.C. Investigation of CMV disease in immunocompromised patients. J. Clin. Pathol. 2001, 54, 84-88. [CrossRef] [PubMed]

3. Dupont, L.; Reeves, M.B. Cytomegalovirus latency and reactivation: Recent insights into an age old problem. Rev. Med. Virol. 2016, 26, 75-89. [CrossRef] [PubMed]

4. Gurczynski, S.J.; Das, S.; Pellett, P.E. Deletion of the Human Cytomegalovirus US17 Gene Increases the Ratio of Genomes per Infectious Unit and Alters Regulation of Immune and Endoplasmic Reticulum Stress Response Genes at Early and Late Times after Infection. J. Virol. 2014, 88, 2168-2182. [CrossRef]

5. Tandon, R.; Mocarski, E.S. Viral and host control of cytomegalovirus maturation. Trends Microbiol. 2012, 20, 392-401. [CrossRef]

6. Lučin, P.; Jug Vučko, N.; Karleuša, L.; Mahmutefendić Lučin, H.; Blagojević Zagorac, G.; Lisnić, B.; Pavišić, V.; Marcelić, M.; Grabušić, K.; Brizić, I.; et al. Cytomegalovirus Generates Assembly Compartment in the Early Phase of Infection by Perturbation of Host-Cell Factors Recruitment at the Early Endosome/Endosomal Recycling Compartment/Trans-Golgi Interface. Front. Cell Dev. Biol. 2020, 8, 563607. [CrossRef]

7. Karleuša, L.; Mahmutefendić, H.; Tomaš, M.I.; Zagorac, G.B.; Lučin, P. Landmarks of endosomal remodeling in the early phase of cytomegalovirus infection. Virology 2018, 515, 108-122. [CrossRef] [PubMed]

8. Cepeda, V.; Esteban, M.; Fraile-Ramos, A. Human cytomegalovirus final envelopment on membranes containing both trans-Golgi network and endosomal markers. Cell. Microbiol. 2010, 12, 386-404. [CrossRef]

9. Das, S.; Vasanji, A.; Pellett, P.E. Three-Dimensional Structure of the Human Cytomegalovirus Cytoplasmic Virion Assembly Complex Includes a Reoriented Secretory Apparatus. J. Virol. 2007, 81, 11861-11869. [CrossRef]

10. Das, S.; Pellett, P.E. Spatial Relationships between Markers for Secretory and Endosomal Machinery in Human CytomegalovirusInfected Cells versus Those in Uninfected Cells. J. Virol. 2011, 85, 5864-5879. [CrossRef] 
11. Rebmann, G.M.; Grabski, R.; Sanchez, V.; Britt, W.J. Phosphorylation of Golgi Peripheral Membrane Protein Grasp65 Is an Integral Step in the Formation of the Human Cytomegalovirus Cytoplasmic Assembly Compartment. mBio 2016, 7, e01554-16. [CrossRef]

12. Lučin, P.; Kareluša, L.; Blagojević Zagorac, G.; Mahmutefendić Lučin, H.; Pavišić, V.; Jug Vučko, N.; Lukanović Jurić, S.; Marcelić, M.; Lisnić, B.; Jonjić, S. Cytomegaloviruses Exploit Recycling Rab Proteins in the Sequential Establishment of the Assembly Compartment. Front. Cell Dev. Biol. 2018, 6, 165. [CrossRef]

13. Hongu, T.; Kanaho, Y. Activation machinery of the small GTPase Arf6. Adv. Biol. Regul. 2014, 54, 59-66. [CrossRef]

14. Donaldson, J.G.; Jackson, C.L. ARF family G proteins and their regulators: Roles in membrane transport, development and disease. Nat. Rev. Mol. Cell Biol. 2011, 12, 362-375. [CrossRef] [PubMed]

15. Lopes-Da-Silva, M.; McCormack, J.J.; Burden, J.J.; Harrison-Lavoie, K.J.; Ferraro, F.; Cutler, D.F. A GBF1-Dependent Mechanism for Environmentally Responsive Regulation of ER-Golgi Transport. Dev. Cell 2019, 49, 786-801.e6. [CrossRef] [PubMed]

16. Grant, B.D.; Donaldson, J.G. Pathways and mechanisms of endocytic recycling. Nat. Rev. Mol. Cell Biol. 2009, 10, 597-608. [CrossRef] [PubMed]

17. D'Souza-Schorey, C.; Chavrier, P. ARF proteins: Roles in membrane traffic and beyond. Nat. Rev. Mol. Cell Biol. 2006, 7, 347-358. [CrossRef]

18. Saraste, J.; Goud, B. Functional Symmetry of Endomembranes. Mol. Biol. Cell 2007, 18, 1430-1436. [CrossRef] [PubMed]

19. Brown, F.D.; Rozelle, A.L.; Yin, H.L.; Balla, T.; Donaldson, J.G. Phosphatidylinositol 4,5-bisphosphate and Arf6-regulated membrane traffic. J. Cell Biol. 2001, 154, 1007-1018. [CrossRef]

20. Sztul, E.; Chen, P.-W.; Casanova, J.E.; Cherfils, J.; Dacks, J.B.; Lambright, D.G.; Lee, F.-J.S.; Randazzo, P.A.; Santy, L.C.; Schürmann, A.; et al. ARF GTPases and their GEFs and GAPs: Concepts and challenges. Mol. Biol. Cell 2019, 30, $1249-1271$. [CrossRef]

21. Cockcroft, S.; Thomas, G.; Fensome, A.; Geny, B.; Cunningham, E.; Gout, I.; Hiles, I.; Totty, N.; Truong, O.; Hsuan, J. Phospholipase D: A downstream effector of ARF in granulocytes. Science 1994, 263, 523-526. [CrossRef]

22. Li, M.; Tian, L.; Yao, H.; Lu, J.; Ge, J.; Guo, Y.; Liu, M.; Xiao, H. ASAP1 mediates the invasive phenotype of human laryngeal squamous cell carcinoma to affect survival prognosis. Oncol. Rep. 2014, 31, 2676-2682. [CrossRef] [PubMed]

23. Kahn, R.A.; Cherfils, J.; Elias, M.; Lovering, R.C.; Munro, S.; Schurmann, A. Nomenclature for the human Arf family of GTP-binding proteins: ARF, ARL, and SAR proteins. J. Cell Biol. 2006, 172, 645-650. [CrossRef] [PubMed]

24. Kondo, Y.; Hanai, A.; Nakai, W.; Katoh, Y.; Nakayama, K.; Shin, H.-W. ARF1 and ARF3 Are Required for the Integrity of Recycling Endosomes and the Recycling Pathway. Cell Struct. Funct. 2012, 37, 141-154. [CrossRef] [PubMed]

25. Nakai, W.; Kondo, Y.; Saitoh, A.; Naito, T.; Nakayama, K.; Shin, H.-W. ARF1 and ARF4 regulate recycling endosomal morphology and retrograde transport from endosomes to the Golgi apparatus. Mol. Biol. Cell 2013, 24, 2570-2581. [CrossRef]

26. Naslavsky, N.; Weigert, R.; Donaldson, J.G. Characterization of a Nonclathrin Endocytic Pathway: Membrane Cargo and Lipid Requirements. Mol. Biol. Cell 2004, 15, 3542-3552. [CrossRef] [PubMed]

27. Ishizaki, R.; Shin, H.-W.; Mitsuhashi, H.; Nakayama, K. Redundant Roles of BIG2 and BIG1, Guanine-Nucleotide Exchange Factors for ADP-Ribosylation Factors in Membrane Traffic between the trans-Golgi Network and Endosomes. Mol. Biol. Cell 2008, 19, 2650-2660. [CrossRef]

28. Boal, F.; Stephens, D.J. Specific Functions of BIG1 and BIG2 in Endomembrane Organization. PLoS ONE 2010, 5, e9898. [CrossRef]

29. Cao, X.; Coskun, Ü.; Rössle, M.; Buschhorn, S.B.; Grzybek, M.; Dafforn, T.R.; Lenoir, M.; Overduin, M.; Simons, K. Golgi protein FAPP2 tubulates membranes. Proc. Natl. Acad. Sci. USA 2009, 106, 21121-21125. [CrossRef]

30. Manolea, F.; Chun, J.; Chen, D.W.; Clarke, I.; Summerfeldt, N.; Dacks, J.B.; Melançon, P. Arf3 Is Activated Uniquely at the trans-Golgi Network by Brefeldin A-inhibited Guanine Nucleotide Exchange Factors. Mol. Biol. Cell 2010, 21, 1836-1849. [CrossRef]

31. Kumari, S.; Mayor, S. ARF1 is directly involved in dynamin-independent endocytosis. Nat. Cell Biol. 2008, 10, 30-41. [CrossRef]

32. Chavrier, P.; Ménétrey, J. Toward a Structural Understanding of Arf Family:Effector Specificity. Structure 2010, 18, 1552-1558. [CrossRef]

33. Van Acker, T.; Tavernier, J.; Peelman, F. The Small GTPase Arf6: An Overview of Its Mechanisms of Action and of Its Role in Host-Pathogen Interactions and Innate Immunity. Int. J. Mol. Sci. 2019, 20, 2209. [CrossRef] [PubMed]

34. Schweitzer, J.K.; Sedgwick, A.E.; D'Souza-Schorey, C. ARF6-mediated endocytic recycling impacts cell movement, cell division and lipid homeostasis. Semin. Cell Dev. Biol. 2011, 22, 39-47. [CrossRef]

35. D'Souza-Schorey, C.; Li, G.; Colombo, M.; Stahl, P. A regulatory role for ARF6 in receptor-mediated endocytosis. Science 1995, 267, 1175-1178. [CrossRef] [PubMed]

36. Mukhamedova, N.; Hoang, A.; Cui, H.L.; Carmichael, I.; Fu, Y.; Bukrinsky, M.; Sviridov, D. Small GTPase ARF6 Regulates Endocytic Pathway Leading to Degradation of ATP-Binding Cassette Transporter A1. Arterioscler. Thromb. Vasc. Biol. 2016, 36, 2292-2303. [CrossRef]

37. Donaldson, J.G.; Johnson, D.L.; Dutta, D. Rab and Arf G proteins in endosomal trafficking and cell surface homeostasis. Small GTPases 2016, 7, 247-251. [CrossRef] [PubMed]

38. Schafer, D.A.; D'Souza-Schorey, C.; Cooper, J.A. Actin Assembly at Membranes Controlled by ARF6. Traffic 2000, 1, 896-907. [CrossRef] [PubMed]

39. Humphreys, D.; Davidson, A.C.; Hume, P.J.; Makin, L.E.; Koronakis, V. Arf6 coordinates actin assembly through the WAVE complex, a mechanism usurped by Salmonella to invade host cells. Proc. Natl. Acad. Sci. USA 2013, 110, 16880-16885. [CrossRef] 
40. Boshans, R.L.; Szanto, S.; van Aelst, L.; D'Souza-Schorey, C. ADP-Ribosylation Factor 6 Regulates Actin Cytoskeleton Remodeling in Coordination with Rac1 and RhoA. Mol. Cell. Biol. 2000, 20, 3685-3694. [CrossRef] [PubMed]

41. Radhakrishna, H.; Donaldson, J.G. ADP-Ribosylation Factor 6 Regulates a Novel Plasma Membrane Recycling Pathway. J. Cell Biol. 1997, 139, 49-61. [CrossRef] [PubMed]

42. Barral, D.C.; Cavallari, M.; McCormick, P.J.; Garg, S.; Magee, A.I.; Bonifacino, J.S.; De Libero, G.; Brenner, M.B. CD1a and MHC Class I Follow a Similar Endocytic Recycling Pathway. Traffic 2008, 9, 1446-1457. [CrossRef] [PubMed]

43. Qi, S.; Su, L.; Li, J.; Zhang, C.; Ma, Z.; Liu, G.; Zhang, Q.; Jia, G.; Piao, Y.; Zhang, S. Arf6-driven endocytic recycling of CD147 determines HCC malignant phenotypes. J. Exp. Clin. Cancer Res. 2019, 38, 1-17. [CrossRef]

44. Montagnac, G.; de Forges, H.; Smythe, E.; Gueudry, C.; Romao, M.; Salamero, J.; Chavrier, P. Decoupling of Activation and Effector Binding Underlies ARF6 Priming of Fast Endocytic Recycling. Curr. Biol. 2011, 21, 574-579. [CrossRef] [PubMed]

45. Jovanovic, O.A.; Brown, F.D.; Donaldson, J.G. An Effector Domain Mutant of Arf6 Implicates Phospholipase D in Endosomal Membrane Recycling. Mol. Biol. Cell 2006, 17, 327-335. [CrossRef]

46. Amor, J.C.; Swails, J.; Zhu, X.; Roy, C.R.; Nagai, H.; Ingmundson, A.; Cheng, X.; Kahn, R.A. The Structure of RalF, an ADPribosylation Factor Guanine Nucleotide Exchange Factor from Legionella pneumophila, Reveals the Presence of a Cap over the Active Site. J. Biol. Chem. 2005, 280, 1392-1400. [CrossRef]

47. Selyunin, A.S.; Reddick, L.E.; Weigele, B.A.; Alto, N.M. Selective Protection of an ARF1-GTP Signaling Axis by a Bacterial Scaffold Induces Bidirectional Trafficking Arrest. Cell Rep. 2014, 6, 878-891. [CrossRef]

48. Wesolowski, J.; Weber, M.M.; Nawrotek, A.; Dooley, C.A.; Calderon, M.; St. Croix, C.M.; Hackstadt, T.; Cherfils, J.; Paumet, F. Chlamydia Hijacks ARF GTPases To Coordinate Microtubule Posttranslational Modifications and Golgi Complex Positioning. mBio 2017, 8, e02280-16. [CrossRef]

49. Ferlin, J.; Farhat, R.; Belouzard, S.; Cocquerel, L.; Bertin, A.; Hober, D.; Dubuisson, J.; Rouillé, Y. Investigation of the role of GBF1 in the replication of positive-sense single-stranded RNA viruses. J. Gen. Virol. 2018, 99, 1086-1096. [CrossRef]

50. Matto, M.; Sklan, E.H.; David, N.; Melamed-Book, N.; Casanova, J.E.; Glenn, J.S.; Aroeti, B. Role for ADP Ribosylation Factor 1 in the Regulation of Hepatitis C Virus Replication. J. Virol. 2010, 85, 946-956. [CrossRef] [PubMed]

51. Verheije, M.H.; Raaben, M.; Mari, M.; te Lintelo, E.G.; Reggiori, F.; Van Kuppeveld, F.J.M.; Rottier, P.J.M.; de Haan, C.A.M. Mouse Hepatitis Coronavirus RNA Replication Depends on GBF1-Mediated ARF1 Activation. PLoS Pathog. 2008, 4, e1000088. [CrossRef] [PubMed]

52. Zeltzer, S.; Zeltzer, C.A.; Igarashi, S.; Wilson, J.; Donaldson, J.G.; Goodrum, F. Virus Control of Trafficking from Sorting Endosomes. mBio 2018, 9, 9. [CrossRef]

53. Crnković-Mertens, I.; Messerle, M.; Milotić, I.; Szepan, U.; Kučić, N.; Krmpotić, A.; Jonjić, S.; Koszinowski, U.H. Virus Attenuation after Deletion of the Cytomegalovirus Fc Receptor Gene Is Not due to Antibody Control. J. Virol. 1998, 72, 1377-1382. [CrossRef] [PubMed]

54. Brizić, I.; Lisnić, B.; Brune, W.; Hengel, H.; Jonjić, S. Cytomegalovirus Infection: Mouse Model. Curr. Protoc. Immunol. 2018, 122, e51. [CrossRef] [PubMed]

55. Angulo, A.; Ghazal, P.; Messerle, M. The Major Immediate-Early Gene ie3 of Mouse Cytomegalovirus Is Essential for Viral Growth. J. Virol. 2000, 74, 11129-11136. [CrossRef]

56. Bolte, S.; Cordelières, F.P. A guided tour into subcellular colocalization analysis in light microscopy. J. Microsc. 2006, 224, 213-232. [CrossRef] [PubMed]

57. Gassmann, M.; Grenacher, B.; Rohde, B.; Vogel, J. Quantifying Western blots: Pitfalls of densitometry. Electrophoresis 2009, 30, 1845-1855. [CrossRef] [PubMed]

58. Tomaš, M.I.; Kučić, N.; Mahmutefendić, H.; Blagojević, G.; Lučin, P. Murine Cytomegalovirus Perturbs Endosomal Trafficking of Major Histocompatibility Complex Class I Molecules in the Early Phase of Infection. J. Virol. 2010, 84, 11101-11112. [CrossRef]

59. Marcinowski, L.; Lidschreiber, M.; Windhager, L.; Rieder, M.; Bosse, J.B.; Rädle, B.; Bonfert, T.; Györy, I.; de Graaf, M.; da Costa, O.P.; et al. Real-time Transcriptional Profiling of Cellular and Viral Gene Expression during Lytic Cytomegalovirus Infection. PLoS Pathog. 2012, 8, e1002908. [CrossRef]

60. Reusch, U.; Muranyi, W.; Lucin, P.; Burgert, H.-G.; Hengel, H.; Koszinowski, U.H. A cytomegalovirus glycoprotein re-routes MHC class I complexes to lysosomes for degradation. EMBO J. 1999, 18, 1081-1091. [CrossRef]

61. Kučić, N.; Ilić Tomaš, M.I.; Mahmutefendić, H.; Blagojević, G.; Lučin, P. Early Endosomal Retention of Murine Cytomegalovirus m06 Protein. Croat. Chem. Acta 2012, 85, 213-221. [CrossRef]

62. Igor, Š.; Natalia, J.V.; Gordana, B.Z.; Marcelić, M.; Lučin, H.M. Dynamin inhibitors prevent the establishment of the cytomegalovirus assembly compartment in the early phase of infection. Life 2021. resubmitted after minor revision.

63. Hosaka, M.; Toda, K.; Takatsu, H.; Torii, S.; Murakami, K.; Nakayama, K. Structure and Intracellular Localization of Mouse ADP-Ribosylation Factors Type 1 to Type 6 (ARF1-ARF6). J. Biochem. 1996, 120, 813-819. [CrossRef] [PubMed]

64. Cohen, L.A.; Donaldson, J.G. Analysis of Arf GTP-Binding Protein Function in Cells. Curr. Protoc. Cell Biol. 2010, 48, 14.12.114.12.17. [CrossRef] [PubMed]

65. Weekes, M.P.; Tomasec, P.; Huttlin, E.L.; Fielding, C.A.; Nusinow, D.; Stanton, R.J.; Wang, E.C.Y.; Aicheler, R.; Murrell, I.; Wilkinson, G.W.G.; et al. Quantitative Temporal Viromics: An Approach to Investigate Host-Pathogen Interaction. Cell 2014, 157, 1460-1472. [CrossRef] [PubMed] 
66. D'Souza, R.S.; Semus, R.; Billings, E.A.; Meyer, C.B.; Conger, K.; Casanova, J.E. Rab4 Orchestrates a Small GTPase Cascade for Recruitment of Adaptor Proteins to Early Endosomes. Curr. Biol. 2014, 24, 1187-1198. [CrossRef]

67. Volpicelli-Daley, L.A.; Li, Y.; Zhang, C.-J.; Kahn, R.A. Isoform-selective Effects of the Depletion of ADP-Ribosylation Factors 1-5 on Membrane Traffic. Mol. Biol. Cell 2005, 16, 4495-4508. [CrossRef] [PubMed]

68. Honda, A.; Al-Awar, O.S.; Hay, J.C.; Donaldson, J.G. Targeting of Arf-1 to the early Golgi by membrin, an ER-Golgi SNARE. J. Cell Biol. 2005, 168, 1039-1051. [CrossRef] [PubMed]

69. Mazelova, J.; Astuto-Gribble, L.; Inoue, H.; Tam, B.M.; Schonteich, E.; Prekeris, R.; Moritz, O.L.; Randazzo, P.A.; Deretic, D. Ciliary targeting motif VxPx directs assembly of a trafficking module through Arf4. EMBO J. 2009, 28, 183-192. [CrossRef]

70. Lowery, J.; Szul, T.; Styers, M.; Holloway, Z.; Oorschot, V.; Klumperman, J.; Sztul, E. The Sec7 Guanine Nucleotide Exchange Factor GBF1 Regulates Membrane Recruitment of BIG1 and BIG2 Guanine Nucleotide Exchange Factors to the Trans-Golgi Network (TGN). J. Biol. Chem. 2013, 288, 11532-11545. [CrossRef]

71. Chun, J.; Shapovalova, Z.; Dejgaard, S.Y.; Presley, J.F.; Melançon, P. Characterization of Class I and II ADP-Ribosylation Factors (Arfs) in Live Cells: GDP-bound Class II Arfs Associate with the ER-Golgi Intermediate Compartment Independently of GBF1. Mol. Biol. Cell 2008, 19, 3488-3500. [CrossRef]

72. Moravec, R.; Conger, K.K.; D'Souza, R.; Allison, A.B.; Casanova, J.E. BRAG2/GEP100/IQSec1 Interacts with Clathrin and Regulates $\alpha 5 \beta 1$ Integrin Endocytosis through Activation of ADP Ribosylation Factor 5 (Arf5). J. Biol. Chem. 2012, 287, 3113831147. [CrossRef] [PubMed]

73. Kobayashi, H.; Fukuda, M. Rab35 regulates Arf6 activity through centaurin $\beta 2$ /ACAP2 during neurite outgrowth. J. Cell Sci. 2012, 125, 2235-2243. [CrossRef]

74. Homma, Y.; Fukuda, M. Rabin8 regulates neurite outgrowth in both GEF activity-dependent and -independent manners. Mol. Biol. Cell 2016, 27, 2107-2118. [CrossRef] [PubMed]

75. Dutta, D.; Donaldson, J.G. Rab and Arf G proteins in endosomal trafficking. Methods Cell Biol. 2015, 130, 127-138. [PubMed]

76. Biesemann, A.; Gorontzi, A.; Barr, F.; Gerke, V. Rab35 protein regulates evoked exocytosis of endothelial Weibel-Palade bodies. J. Biol. Chem. 2017, 292, 11631-11640. [CrossRef] [PubMed]

77. Klinkert, K.; Rocancourt, M.; Houdusse, A.; Echard, A. Rab35 GTPase couples cell division with initiation of epithelial apico-basal polarity and lumen opening. Nat. Commun. 2016, 7, 11166. [CrossRef]

78. Bottanelli, F.; Kilian, N.; Ernst, A.M.; Rivera-Molina, F.; Schroeder, L.K.; Kromann, E.B.; Lessard, M.D.; Erdmann, R.S.; Schepartz, A.; Baddeley, D.; et al. A novel physiological role for ARF1 in the formation of bidirectional tubules from the Golgi. Mol. Biol. Cell 2017, 28, 1676-1687. [CrossRef] [PubMed]

79. Zulkefli, K.L.; Mahmoud, I.S.; Williamson, N.A.; Gosavi, P.K.; Houghton, F.J.; Gleeson, P.A. A role for Rab30 in retrograde trafficking and maintenance of endosome-TGN organization. Exp. Cell Res. 2021, 399, 112442. [CrossRef]

80. Donaldson, J.G.; Honda, A.; Weigert, R. Multiple activities for Arf1 at the Golgi complex. Biochim. Biophys. Acta Mol. Cell Res. 2005, 1744, 364-373. [CrossRef]

81. Eyster, C.A.; Higginson, J.D.; Huebner, R.; Porat-Shliom, N.; Weigert, R.; Wu, W.W.; Shen, R.-F.; Donaldson, J.G. Discovery of New Cargo Proteins that Enter Cells through Clathrin-Independent Endocytosis. Traffic 2009, 10, 590-599. [CrossRef]

82. Moghimi, S.; Viktorova, E.; Zimina, A.; Szul, T.; Sztul, E.; Belov, G.A. Enterovirus Infection Induces Massive Recruitment of All Isoforms of Small Cellular Arf GTPases to the Replication Organelles. J. Virol. 2020, 95, 95. [CrossRef]

83. Belov, G.A.; Fogg, M.H.; Ehrenfeld, E. Poliovirus Proteins Induce Membrane Association of GTPase ADP-Ribosylation Factor. J. Virol. 2005, 79, 7207-7216. [CrossRef]

84. Wang, J.; Du, J.; Jin, Q. Class I ADP-Ribosylation Factors Are Involved in Enterovirus 71 Replication. PLoS ONE 2014, 9, e99768. [CrossRef]

85. Lanke, K.H.W.; van der Schaar, H.M.; Belov, G.A.; Feng, Q.; Duijsings, D.; Jackson, C.L.; Ehrenfeld, E.; van Kuppeveld, F.J.M. GBF1, a Guanine Nucleotide Exchange Factor for Arf, Is Crucial for Coxsackievirus B3 RNA Replication. J. Virol. 2009, 83, 11940-11949. [CrossRef]

86. Joshi, A.; Garg, H.; Nagashima, K.; Bonifacino, J.S.; Freed, E.O. GGA and Arf Proteins Modulate Retrovirus Assembly and Release. Mol. Cell 2008, 30, 227-238. [CrossRef] [PubMed]

87. Hansen, M.D.; Johnsen, I.B.; Stiberg, K.A.; Sherstova, T.; Wakita, T.; Richard, G.M.; Kandasamy, R.K.; Meurs, E.F.; Anthonsen, M.W. Hepatitis $C$ virus triggers Golgi fragmentation and autophagy through the immunity-related GTPase M. Proc. Natl. Acad. Sci. USA 2017, 114, E3462-E3471. [CrossRef] [PubMed]

88. Lim, Y.-S.; Ngo, H.T.T.; Lee, J.; Son, K.; Park, E.-M.; Hwang, S.B. ADP-ribosylation Factor-related Protein 1 Interacts with NS5A and Regulates Hepatitis C Virus Propagation. Sci. Rep. 2016, 6, 31211. [CrossRef] [PubMed]

89. Babbey, C.M.; Ahktar, N.; Wang, E.; Chen, C.C.-H.; Grant, B.D.; Dunn, K.W. Rab10 Regulates Membrane Transport through Early Endosomes of Polarized Madin-Darby Canine Kidney Cells. Mol. Biol. Cell 2006, 17, 3156-3175. [CrossRef]

90. Wang, X.; Huong, S.-M.; Chiu, M.L.; Raab-Traub, N.; Huang, E.-S. Epidermal growth factor receptor is a cellular receptor for human cytomegalovirus. Nat. Cell Biol. 2003, 424, 456-461. [CrossRef]

91. Soroceanu, L.; Akhavan, A.; Cobbs, C.S. Platelet-derived growth factor- $\alpha$ receptor activation is required for human cytomegalovirus infection. Nat. Cell Biol. 2008, 455, 391-395. [CrossRef] [PubMed] 
92. Lemmermann, N.A.W.; Krmpotic, A.; Podlech, J.; Brizic, I.; Prager, A.; Adler, H.; Karbach, A.; Wu, Y.; Jonjic, S.; Reddehase, M.J.; et al. Non-redundant and Redundant Roles of Cytomegalovirus gH/gL Complexes in Host Organ Entry and Intra-tissue Spread. PLoS Pathog. 2015, 11, e1004640. [CrossRef]

93. Compton, T.; Nepomuceno, R.R.; Nowlin, D.M. Human cytomegalovirus penetrates host cells by PH-independent fusion at the cell surface. Virology 1992, 191, 387-395. [CrossRef]

94. Feire, A.L.; Roy, R.M.; Manley, K.; Compton, T. The Glycoprotein B Disintegrin-Like Domain Binds Beta 1 Integrin To Mediate Cytomegalovirus Entry. J. Virol. 2010, 84, 10026-10037. [CrossRef] [PubMed]

95. Ryckman, B.J.; Jarvis, M.A.; Drummond, D.D.; Nelson, J.A.; Johnson, D.C. Human Cytomegalovirus Entry into Epithelial and Endothelial Cells Depends on Genes UL128 to UL150 and Occurs by Endocytosis and Low-pH Fusion. J. Virol. 2006, 80, 710-722. [CrossRef]

96. Ryckman, B.J.; Rainish, B.L.; Chase, M.C.; Borton, J.A.; Nelson, J.A.; Jarvis, M.A.; Johnson, D.C. Characterization of the Human Cytomegalovirus gH/gL/UL128-131 Complex That Mediates Entry into Epithelial and Endothelial Cells. J. Virol. 2008, 82, 60-70. [CrossRef] [PubMed]

97. Hetzenecker, S.; Helenius, A.; Krzyzaniak, M.A. HCMV Induces Macropinocytosis for Host Cell Entry in Fibroblasts. Traffic 2016, 17, 351-368. [CrossRef] [PubMed]

98. Vanarsdall, A.L.; Pritchard, S.R.; Wisner, T.W.; Liu, J.; Jardetzky, T.S.; Johnson, D.C. CD147 Promotes Entry of Pentamer-Expressing Human Cytomegalovirus into Epithelial and Endothelial Cells. mBio 2018, 9, e00781-18. [CrossRef]

99. Grundy, J.; Super, M.; Sweny, P.; Moorhead, J.; Lui, S.F.; Berry, N.J.; Fernando, O.N.; Griffiths, P.D. Symptomatic Cytomegalovirus Infection in Seropositive Kidney Recipients: Reinfection with Donor Virus Rather than Reactivation of Recipient Virus. Lancet 1988, 332, 132-135. [CrossRef]

100. Li, Q.; Wilkie, A.R.; Weller, M.; Liu, X.; Cohen, J.I. THY-1 Cell Surface Antigen (CD90) Has an Important Role in the Initial Stage of Human Cytomegalovirus Infection. PLoS Pathog. 2015, 11, e1004999. [CrossRef]

101. Stegmann, C.; Hochdorfer, D.; Lieber, D.; Subramanian, N.; Stöhr, D.; Laib Sampaio, K.; Sinzger, C. A derivative of platelet-derived growth factor receptor alpha binds to the trimer of human cytomegalovirus and inhibits entry into fibroblasts and endothelial cells. PLoS Pathog. 2017, 13, e1006273. [CrossRef] [PubMed]

102. Miaczynska, M. Effects of Membrane Trafficking on Signaling by Receptor Tyrosine Kinases. Cold Spring Harb. Perspect. Biol. 2013, 5, a009035. [CrossRef] [PubMed]

103. Klein, S.; Franco, M.; Chardin, P.; Luton, F. Role of the Arf6 GDP/GTP Cycle and Arf6 GTPase-activating Proteins in Actin Remodeling and Intracellular Transport. J. Biol. Chem. 2006, 281, 12352-12361. [CrossRef]

104. García-Expósito, L.; Barroso-González, J.; Puigdomènech, I.; Machado, J.-D.; Blanco, J.; Valenzuela-Fernández, A. HIV-1 requires Arf6-mediated membrane dynamics to efficiently enter and infect T lymphocytes. Mol. Biol. Cell 2011, 22, 1148-1166. [CrossRef] [PubMed]

105. Ono, A.; Ablan, S.D.; Lockett, S.J.; Nagashima, K.; Freed, E.O. Phosphatidylinositol $(4,5)$ bisphosphate regulates HIV-1 Gag targeting to the plasma membrane. Proc. Natl. Acad. Sci. USA 2004, 101, 14889-14894. [CrossRef]

106. Heikkilä, O.; Susi, P.; Tevaluoto, T.; Härmä, H.; Marjomäki, V.; Hyypiä, T.; Kiljunen, S. Internalization of Coxsackievirus A9 Is Mediated by $32-$ Microglobulin, Dynamin, and Arf6 but Not by Caveolin-1 or Clathrin. J. Virol. 2010, 84, 3666-3681. [CrossRef]

107. Mercer, J.; Helenius, A. Vaccinia Virus Uses Macropinocytosis and Apoptotic Mimicry to Enter Host Cells. Science 2008, 320, 531-535. [CrossRef] [PubMed]

108. Tugizov, S.M.; Herrera, R.; Palefsky, J.M. Epstein-Barr Virus Transcytosis through Polarized Oral Epithelial Cells. J. Virol. 2013, 87, 8179-8194. [CrossRef]

109. Vidricaire, G.; Imbeault, M.; Tremblay, M.J. Endocytic Host Cell Machinery Plays a Dominant Role in Intracellular Trafficking of Incoming Human Immunodeficiency Virus Type 1 in Human Placental Trophoblasts. J. Virol. 2004, 78, 11904-11915. [CrossRef]

110. Procter, D.J.; Banerjee, A.; Nukui, M.; Kruse, K.; Gaponenko, V.; Murphy, E.A.; Komarova, Y.; Walsh, D. The HCMV Assembly Compartment Is a Dynamic Golgi-Derived MTOC that Controls Nuclear Rotation and Virus Spread. Dev. Cell 2018, 45, 83-100.e7. [CrossRef]

111. Drin, G.; Morello, V.; Casella, J.-F.; Gounon, P.; Antonny, B. Asymmetric Tethering of Flat and Curved Lipid Membranes by a Golgin. Science 2008, 320, 670-673. [CrossRef] [PubMed]

112. Ríos, R.M.; Sanchís, A.; Tassin, A.M.; Fedriani, C.; Bornens, M. GMAP-210 Recruits $\gamma$-Tubulin Complexes to cis-Golgi Membranes and Is Required for Golgi Ribbon Formation. Cell 2004, 118, 323-335. [CrossRef] [PubMed]

113. Wong, M.; Munro, S. The specificity of vesicle traffic to the Golgi is encoded in the golgin coiled-coil proteins. Science 2014, 346, 1256898. [CrossRef] [PubMed]

114. Gilbert, C.E.; Sztul, E.; Machamer, C.E. Commonly used trafficking blocks disrupt ARF1 activation and the localization and function of specific Golgi proteins. Mol. Biol. Cell 2018, 29, 937-947. [CrossRef] [PubMed]

115. Bui, Q.T.; Golinelli-Cohen, M.-P.; Jackson, C.L. Large Arf1 guanine nucleotide exchange factors: Evolution, domain structure, and roles in membrane trafficking and human disease. Mol. Genet. Genom. 2009, 282, 329-350. [CrossRef] [PubMed]

116. Galindo, A.; Soler, N.; McLaughlin, S.H.; Yu, M.; Williams, R.L.; Munro, S. Structural Insights into Arl1-Mediated Targeting of the Arf-GEF BIG1 to the trans-Golgi. Cell Rep. 2016, 16, 839-850. [CrossRef] 